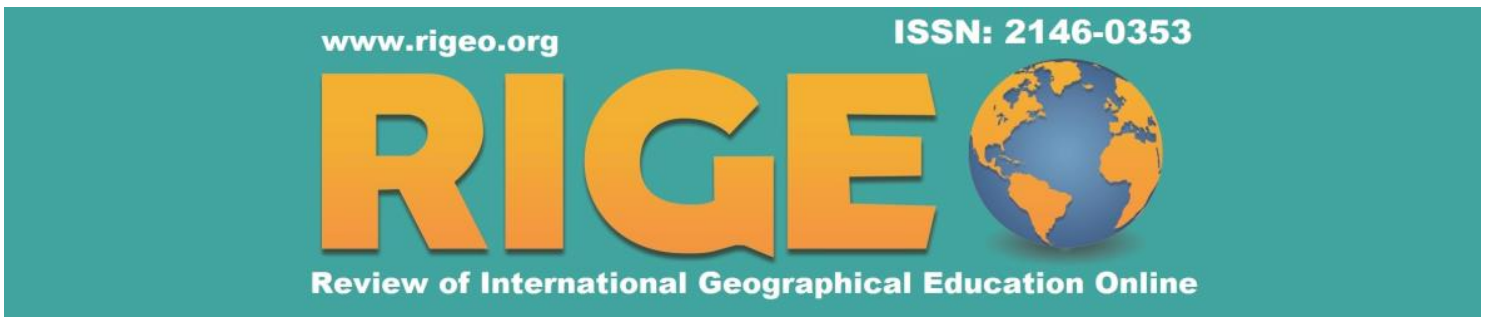

Review of International Geographical Education Online

CRIGEO Volume 8, Number 3, Winter 2018

Research Article

Copyright @ RIGEO 2018

To cite this article: Köşker, N.; Özgen, N. (2018). Multiculturality Concept and Its Reflections on Education: The Case of Turkey. Review of International Geographical Education Online (RIGEO), 8(3), 571-600. Retrieved from http://www.rigeo.org/vol8no3/Number3winter/RIGEO-V8-N3-9.pdf

Submitted: May 11, $2018 \quad$ Revised: December 4, $2018 \quad$ Accepted: December 14, 2018

\title{
Multiculturality Concept and Its Reflections on Education: The Case of Turkey
}

\author{
Nilüfer KÖŞKER ${ }^{1}$ \\ Faculty of Education, KIrıkkale University, Kırıkkale, TURKEY \\ Nurettin ÖZGEN ${ }^{2}$ \\ Faculty of Languages, History and Geography, Ankara University, Ankara, TURKEY
}

\begin{abstract}
The current study investigated the multiculturality attitudes of high school students using the Multiculturality Attitude Scale. The determination of the dynamics affecting students' multiculturality attitudes will provide opportunities for reconstructing the educational settings accordingly. The sample of the study was 2237 students from 24 high schools from 14 provincial centres in 7 geographical regions of Turkey. The data analysis was carried out using descriptive and inferential statistics. The analyses examined the relationships between the multiculturality attitudes of the students and their gender, class level, family income status, education level of the parents, and the geographic region of residence. The findings indicated significant differences between all dimensions of the scale (i.e., anxiety, richness, tolerance, threat, and discrimination) and the variables of the study. The findings indicated that the female students' attitude mean scores were more positive than those of the male students. Students in Central Anatolia, Southeastern Anatolia, and Marmara regions had higher attitude scores than students from other regions. As students' family income level increases, they regard multiculturality as a threat (ethnicity-based). Students whose parents have a high level of education regard multiculturality as a threat (ethnicity-based). In order to minimize these negative attitudes towards multiculturality in the society, people's awareness of different life practices by various groups within a country or community offers richness that should be recognized. To achieve this, the regulation of educational experiences considering cultural diversity and normalizing transitions, the differences in the educational institutions that serve as foundation in the society-building process are of the utmost importance.
\end{abstract}

Keywords

Turkey; Geographic Regions; Multiculturality; Multicultural Society; Multiculturality Attitude; Multicultural Education

${ }^{1}$ Corresponding author: Dr., Department of Social Studies Education, Faculty of Education, Kırıkkale University, Kırıkkale, Turkey, E-mail: niluferkosker [at] gmail.com.

${ }^{2}$ Assoc. Prof. Dr., Department of Geography, Faculty of Languages, History and Geography, Ankara University,Ankara, Turkey, E-mail: nozgen [at] gmail.com

(C) Review of International Geographical Education Online

RIGEO 2018

ISSN: $2146-0353$

Www.rigeo.org 
Multiculturality is a term that includes the cultural life forms of various groups or societies such as belief, sect, ethnicity, gender roles and economic status. The concept of multiculturality involves interaction-sharing and separation happening together, as well as events and actions being performed through cognitive, affective and dynamic achievements. One of the basic portrayals of this concept is seen in groups or societies, which have many folkloric characteristics, such as political systems, ideologies, beliefs, religions, social roles, values, gender-based attitudes, class-oriented approaches and spatial relations as well as many others feature in a mutual environment (APA, 2002; Baumann, 2006; Modood, 2014; Parekh, 2002; Taylor, 2005).

Although multiculturality brings to mind a colourful landscape of a transitive geographic region or a pastoral painting of a classic painter, it is a paradoxical phenomenon consisting of different effects and, hence, the dualist, dialectic and dichotomist reflections (e.g., beliefs, gender-based approaches and appearance differences) that occur in daily life. The creation and implementation of multicultural policies have entailed a number of problems. Some commentators have considered the concept of multiculturalism as a means of the divide-and-rule strategy by a government in relation to ethnic minorities. In spite of these criticisms, multiculturalism has been successfully mainstreamed (Vertovec, 2010). A multicultural attitude is of prime importance for living harmoniously in a world with swift global interactions and cultural exchanges. In developed or ideal societies where the multicultural life form is effective, ethnic structures, beliefs, religions, different sexual orientations, and many other moral and material differences can be smoothly and justly represented. In the representation of these differences, education and related policies in which social engineering is built play a particularly important role as these policies identify the behaviors to be acquired during the educational process and they ensure that citizens are equipped with the social, cultural and political attitudes that help preserve the existing social structure. Social, cultural and political attitudes gained by the individuals in educational institutions lead to the building of some attitudes oriented towards multiculturality by spreading social and cultural environments via these institutions. Although these attitudes can lead to positive effects in terms of social diversity, they can also form the basis for some negative effects and the form of "others". These negative effects create a basis for raising individuals who regard multiculturality not as richness, but as a threat or discrimination and develop attitudes against people or groups from different cultures. Otherizing based on differences feed mistrust for the other and anxiety by weakening the will to live together and by eroding tolerance. In such cases, views, which adversely affect or prevent the cohabitation of diverse cultural structures, may emerge. According to Keyman (2007, p. 227), "the basic troubles of the world and Turkey today involve "how to achieve unity from diversity" and "how to preserve diversity within unity". It is important that the differences, which constitute cultural diversity in a society, can protect their own colors and at the same time interact in harmony as parts of a whole. According to Parekh (2002, p.251), a multicultural society cannot ignore the demands of diversity, while it must create a strong sense of coexistence and shared belonging among its citizens. In this context, multiculturalism constitutes the basis for preserving cultural diversity and strengthening the feelings of 
equality and unity within the social structure. A specific example for multicultural practices from around the world may be given from Canada. The state of Canada views the differences of all its citizens as its own capital. Canada advocates a social structure in which each community can survive within its own culture (Özensel, 2012).

Parekh (2002) writes that "cultural diversity is an important constituent and prerequisite for human freedom. If people cannot go beyond their culture, they remain arrested in it. They consider it absolute and believe that it is the only natural or open path to perceiving and organizing human life. If they do not reach out for other cultures, they remain trapped in theirs". As also mentioned by Banks (2013), individuals who strive to understand the world through their own cultural viewpoint alone are deprived of a significant portion of human experience, and are culturally and ethnically restricted. Owing to their own cultural prejudice, these individuals do not know their own cultures fully either. Going beyond one's culture, recognizing diverse cultural structures, and developing a new way of understanding relies particularly on education. It is through education that individuals get to know the cultural structure they are born into as well as other external cultural forms, and thus develop a multiculturality attitude. This is the way to recognizing, understanding, respecting and effectively interacting with other cultures (Açıkalın, 2010; Banks, 2013; Banks, 2016; Cırık, 2008; Gay, 2014).

Education also plays an outstanding role in raising individuals who have a biased approach to different social groups and develop negative attitudes towards them. Thus, according to Wilcox and Nolte (1990, as cited in Oktay 1996), factors affecting individual attitudes usually have social characteristics such as the important factors of family, education, economic status, group membership, experiences, the neighbourhood, race, religious beliefs, national origin, favourite political party, occupation, social class and special interest areas. In fact, according to Taylor (2005, p.72), we should all accept the equal value possessed by different cultures and let those cultures maintain their particular practices and beliefs. In this context, according to Wolf (2005, p. 85- 86):

The most significant negatives related to the members of unrecognized cultures, from the most optimistic viewpoint, are their feelings of emptiness and separation from their origins due to the lack of resources to develop their self-esteem and create the spirit of belonging to a society. From the worst perspective, they face the risk of being culturally destroyed. The most obvious solution is to promote, treasure and openly protect the cultural traditions and achievements of people who are the descendants of different cultures.

The educational view adopted in multicultural Turkey, in line with the ethos of being a nation state, is based on the goal of forming a homogeneous society where diverse cultural structures are defined over one single identity (Fortna, 2013; Öztan, 2011; Ulugöl, 2009; Üstel, 2014). It is worth noting that designing a homogeneous society involves ignoring or pushing aside the different elements of a society, or assuming that such diferences will eventually be eliminated by the existing or desired homogeneity (Günay, 2010). The nation-state rejects the notion that ethnicity is its defining feature. In the nation-state, citizenship means being loyal to the nation as a political community. This, in fact, is designed to transcend cultural and ethnic 
differences (Weldon, 2006). Therefore, educational policies were built on a citizenship design not based on a multicultural view. Particularly during the early years of the Republic, the main goal of national education was to melt away or assimilate "foreign cultures" and thus build a uniform Turkish nation. National education thus became a tool for the state to propagate this national politics and make it the expected behavioral norm (Kaplan, 2008). As stated by Üstel (2014, p. 327-328), this understanding of education prominent in the early years of the Republic shifted from being an ethnocultural citizenship view to a political citizenship view which adhered to the national borders in the 1950s, and then to a more religious view from the second half of the 1980 s with the "Citizenship Studies" textbook, which was an educational manifestation of the 12 September spirit. Islam was now considered an important element of citizenship. The new nation was desired to have a single ethnic structure, a single language and a single religion. In accord with this goal, education was seen as the most important element of national unity and curricula were designed accordingly. The educational content of today is still largely determined with this viewpoint (Çayır, 2003), which in turn leads to "prejudice against different countries and cultures", as expressed by Gök (2003, p. 160). It may therefore be argued that the Turkish education system is in need of a philosophy change, and that practices not based on freedom and equality will further deepen social problems (Kaplan, 2005, p. 397).

Turkey has a rich cultural heritage. Therefore, a multicultural educational content is important for the development of the ability to coexist in Turkey. In this context, the reflection of cultural diversity on educational content has become a necessity. However, from the first years of the republic in the education system, textbooks and curriculum have become the main tools of the idea of a homogenous society. In this process, apart from the courses necessary to provide the unity of language, religion, and history, the geography course has been employed in the construction of the place that constitutes the homeland of the state.

One of the most important courses that reflected the cultural diversity in Turkey is geography. However, geography lessons show a characteristic that includes the thought of a space dominated by Turkish identity, which ignores cultural diversity (ethnic, linguistic, religious). Such geography education is called "unmanned geography" or "landscape geography" (H. N. Özgen, 2011). This situation continues today in the curriculum and textbooks of various courses (Çayır, 2016). According to Özgen (2016), human geography curricula have been aligned with the nationalist and hegemonic power politics of state authorities instead of universal norms, thus ignoring Turkey's sociopolitical and cultural geography. This is reflected in the contents of human geography textbooks at the high school and college level. For example, the nationalist language and approach used in $12^{\text {th }}$ grade geography textbook when referring to the sociocultural and geopolitical importance of Turkey clearly reveal the political (nationalist) approaches of state authorities. This situation is all about power and authoritarianity.

Hobbes' expression that laws are made by authorities, not by truth (Schmitt, 2010), validates this approach. Geographical-spatial information is organized to provide a 
functional framework for the efforts of the powerful to dominate the space (Özgen, 2011; 2012a; 2012b; 2013b) and is used as an ideological tool in Althusser's (2015) words. This establishes a mutual relationship between knowledge and power (Foucault, 2011). As a result of these, the structure constructed by power keeps reproducing itself. As stated by Lacoste (1998, p.37), a typical example is the use of openly chauvinistic geography books that still hide internal political problems (or themes that may potentially cause problems). In this context, curriculums and textbooks are tools of transmitting state ideology instead of fieldwork concerning homeland knowledge. The ideology of creating a homogenous society in which differences are ignored leads to the perception of the other cultures as a source of the threat.

In Turkey, studies oriented towards defining individuals' perceptions, attitudes, and views on multiculturality have been undertaken by academicians, prospective teachers, school administrators and teachers (Akkaya, Kırmızı \& İşçi, 2018; Aslan, 2017; Avc1 \& Faiz, 2018; Coşkun, 2012; Damgacı \& Aydın, 2013; Demir 2012; Demir \& Başarır, 2013; Demirsoy, 2013; Güngör, Buyruk \& Özdemir, 2018; Kahraman \& Sezer, 2017; Karaçam \& Koca, 2012; Kaya \& Söylemez, 2014; Nayır \& Çetin, 2018; Özdemir \& Dil, 2013; Polat, 2012; Üzülmez \& Karakuş, 2018), and the extent to which curricula and textbooks include multiculturality was investigated (Açıkalın, 2010; Akar \& Keyvanoğlu, 2016; Akhan \& Yalçın, 2016; Cırık, 2008; Çayır, 2016; Keskin \& Yaman, 2014; Seban \& Uyanık, 2016). These studies have shown that while Turkish teacher candidates, teachers, administrators and academicians view multiculturality and multicultural education in a positive light, curricula and textbooks have many deficiencies. Course books are still written with an understanding of national culture that ignores different ethnic cultures, languages, and religions in Turkey (Çayır, 2016). Therefore, educational policies are still not equipped to bring multiculturality into educational settings.

This plethora of study into multiculturality means that we can no longer stick our heads into sand and ignore the problems related to the topic; moreover, procrastinating the engagement in discussions has become impossible (Kymlicka, 1998). Within this context, as educational institutions have the most important role in building societies, one of their most fundamental requirements is to raise students' awareness in terms of the representation and richness of the social differences. Considering the fact that the learners are the representatives of the "different worlds" and carry the cognitive and affective imprint of the socioeconomic and cultural aspects of the environments in which they grew up (Özgen, 2013a; 2013b), the teaching of these differences has the utmost importance in terms of social agreement and the skills of living together. Thus, this awareness must include a structure and process from the primary school years to all the stages of higher education. In this concept, the experiment of Jane Elliott (see Bloom, 2005) is worth exemplifying. In sum, it is necessary to identify the social dynamics which may either make students tolerant towards other cultural structures and see multiculturality as a source of richness, or conversely make them see other cultures as threats and cause them to develop an anxious and discriminatory view, and to reconstruct educational settings accordingly. Therefore, it is crucial to foster positive 
attitudes, empathy and communication skills to interact with students from different cultural backgrounds.

This study is the part of a multi-dimensional field survey which addresses to the high school students' multiculturality attitudes. In this study aims to analyze the relationships between high school students' multiculturality attitudes (Anxiety, Richness, Tolerance, Threat, and Discrimination) and their:

- Gender,

- Class level

- Family income level

- Parental education status

- Geographical region where they reside.

The relationship between students' socio-cultural identity definitions (ethnicity, religion and sect, etc.) and their multiculturality attitudes is discussed for another study (Özgen \& Köşker, 2019). Therefore, the relationship between students' socio-cultural identity definitions (ethnicity, religion and sect, etc.) and their multiculturality attitudes is beyond the scope of this study.

\section{Limitations}

It aimed to collect data from Turkey's seven regions in this study. However, due to the difficulties of accessing and practicing the schools in these regions, easily accessible cities and schools have been included in the research. It has been reached the schools in the provinces where the researchers can easily reach.

Participants from the $10^{\text {th }}, 11^{\text {th }}$ and $12^{\text {th }}$ grades were included in the study to ensure that students did not have difficulty in understanding and responding to the items in the measurement tool, and therefore, the $9^{\text {th }}$ grade was excluded from the study.

\section{Methodology}

This study is a descriptive field study in which a survey model is used based on an assessment instrument. Survey model gather data with the intention of describing the nature of existing conditions or determining the relationships that exist between specific events (Cohen, Manion \& Morrison, 2007). A survey design provides a quantitative or numeric description of trends, attitudes or opinions (Creswell, 2009). 


\section{Participants}

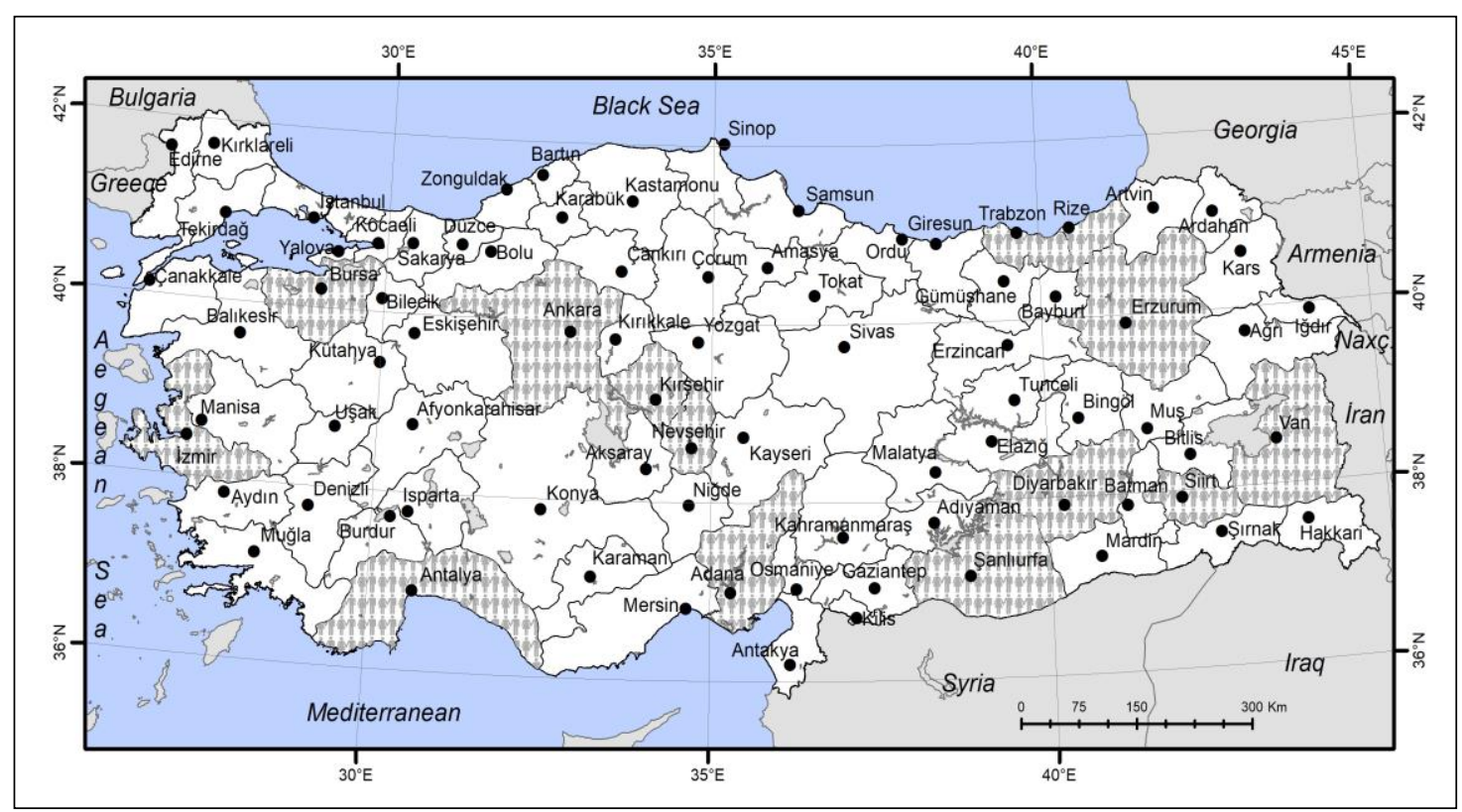

Figure 1. Provinces selected for inclusion in the research.

In determinate the participants aimed to reach high school students in Turkey's seven geographical regions. In this context, 14 provinces were selected, with the convenience sampling method from the seven geographical regions in Turkey (Figure 1). In the selection of provinces, easy accessibility was taken into consideration.

The following cities and regions were reached for the sampling: Bursa (Marmara), Trabzon and Rize (Black Sea), Izmir (Aegean), Ankara, Kırşehir, and Nevşehir (Central Anatolia), Adana and Antalya (Mediterranean), Erzurum and Van (East Anatolia) and Siirt, Diyarbakır, and Şanlıurfa (Southeast Anatolia). The participants were high school students in the $10^{\text {th }}, 11^{\text {th }}$, and $12^{\text {th }}$ grades of 24 high schools in the 14 provinces (total 2237 participants). The main demographic information concerning the participants is given in Table 1.

Table 1

Democraphic Characteristics of Participants in the Research Sample

\begin{tabular}{llcc}
\hline Variables & Options & n & \% \\
\hline \multirow{2}{*}{ Gender } & Female & 1291 & 57.7 \\
\cline { 2 - 4 } & Male & 946 & 42.3 \\
\hline \multirow{3}{*}{ Class Level } & 10 & 701 & 31.3 \\
\cline { 2 - 4 } & 11 & 986 & 44.1 \\
\cline { 2 - 4 } & 12 & 550 & 24.6 \\
\hline \multirow{4}{*}{$\begin{array}{l}\text { Family Monthly } \\
\text { Income }\end{array}$} & Lower than 1000 TL (Turkish & 783 & 35.0 \\
& Lira) & & \\
\cline { 2 - 4 } & Between 1001-2000 TL & 599 & 26.8 \\
\cline { 2 - 4 } & Between 2001-3000 TL & 499 & 22.3 \\
\cline { 2 - 4 } & More than 3000 TL & 356 & 15.9 \\
\hline
\end{tabular}


Köşker, N., Özgen, N. (2018) Multiculturality concept and its reflections on education: The case of....

\begin{tabular}{|c|c|c|c|}
\hline \multirow{7}{*}{$\begin{array}{l}\text { Father Educational } \\
\text { Status }\end{array}$} & Illiterate & 110 & 4.9 \\
\hline & $\begin{array}{l}\text { Literate (outside the school } \\
\text { system) }\end{array}$ & 106 & 4.7 \\
\hline & Primary School & 598 & 26.7 \\
\hline & Secondary School & 372 & 16.6 \\
\hline & High School & 596 & 26.6 \\
\hline & University & 388 & 17.3 \\
\hline & Post-graduate & 67 & 3.0 \\
\hline \multirow{7}{*}{$\begin{array}{l}\text { Mother Educational } \\
\text { Status }\end{array}$} & Illiterate & 450 & 20.1 \\
\hline & $\begin{array}{l}\text { Literate (outside the school } \\
\text { system) }\end{array}$ & 114 & 5.1 \\
\hline & Primary School & 651 & 29.1 \\
\hline & Secondary School & 320 & 14.3 \\
\hline & High School & 481 & 21.5 \\
\hline & University & 205 & 9.2 \\
\hline & Post-graduate & 16 & 0.7 \\
\hline \multirow{8}{*}{ Geographical Region } & Marmara Region & 264 & 11.8 \\
\hline & Aegean Region & 279 & 12.5 \\
\hline & Mediterranean Region & 269 & 12.0 \\
\hline & Southeastern Anatolia Region & 384 & 17.2 \\
\hline & Eastern Anatolia Region & 343 & 15.3 \\
\hline & Black Sea Region & 307 & 13.7 \\
\hline & Central Anatolia Region & 391 & 17.5 \\
\hline & Total & 2237 & 100 \\
\hline
\end{tabular}

\section{Data Collection Tool}

The data was collected by using the Multiculturality Attitude Scale developed by Özgen and Köşker (2015). The Multiculturality Attitude Scale were determined via Exploratory Factor Analysis, which determined the validity of the scale. As a result of Exploratory Factor Analysis, which was carried out to define the validity of the scale, a form consisting of 5-dimensions and 21 items was achieved. After Exploratory Factor Analysis, the 5-dimension structure of the scale was confirmed via Confirmatory Factor Analysis. Confirmatory factor analysis showed that the fit indices were at an acceptable level ( $\chi 2 / \mathrm{df:} 1.95$, RMSEA: .06, CFI: .86) and a 5-dimensional structure was confirmed. The overall reliability co-efficient of the scale is .73 .

The Multiculturality Attitude Scale consists of five dimensions (anxiety, richness, tolerance, threat and discrimination) and 21 items (Appendix). Anxiety dimension has six items about cultural features, beliefs, different political views, and social gender roles. Richness dimension has five items about ethnic diversity and religious. Tolerance dimension has three items about people with different sexual orientations. Threat dimension has four items about ethnic groups and languages. Discrimination dimension has three items about disadvantaged groups such as women and the disabled (Özgen \& Köşker, 2019). Participants responded to the statements included in the scale using a 5point Likert-type scale. Negative statements were graded the opposite way. The overall minimum and maximum scores that can be obtained from the scale are 21 and 105, 
respectively. However, the grading varies in each of the five dimensions according to the number of items; the minimum and maximum scores are 6 and 30 in the anxiety dimension; 5 and 25 in the richness dimension; 3 and 15 in the tolerance dimension; 4 and 20 in the threat dimension; and 3 and 15 in the discrimination dimension (Table 2).

Table 2

Mean Scores of the Students

\begin{tabular}{lcccccc}
\hline Dimensions & N & $\begin{array}{c}\text { Number } \\
\text { of Items }\end{array}$ & Minimum & Maximum & $\bar{X}$ & Sd \\
\hline Anxiety & 2237 & 6 & 6 & 30 & 21.0313 & 4.7537 \\
Richness & 2237 & 5 & 5 & 25 & 18.3661 & 3.7239 \\
Tolerance & 2237 & 3 & 3 & 15 & 8.3049 & 3.5427 \\
Threat & 2237 & 4 & 4 & 20 & 13.5713 & 4.0324 \\
Discrimination & 2237 & 3 & 3 & 15 & 12.3599 & 2.4763 \\
\hline Total & 2237 & 21 & 21 & 105 & 73.6334 & 4.7537 \\
\hline
\end{tabular}

\section{Analysis of Data}

The data collection tool was applied by the researchers and teachers to the students in the second semester of the 2014-2015 (in March, April and May) academic year. In order to see whether the research data had normal distribution, the values of skewness and kurtosis and histograms of the data were examined. According to Kim (2013) "The formal normality tests including Shapiro-Wilk test and Kolmogorov-Smirnov test may be used from small to medium sized samples (e.g., $\mathrm{n}<300$ ), but may be unreliable for large samples". If the study has a large sample (200 or more) it is more important to look at the value of the skewness and kurtosis statistics (Field, 2009). When analyzing Skewness and Kurtosis statistics, both values fall within the range from the acceptable limits of -2.0 to +2.0 (George \& Mallery, 2003; Schutz \& Gessaroli, 1993). These values (Table 3) and histogram graphics indicate that the data have a normal distribution. For this reason, t-test and one-way analysis of variance test (ANOVA) were used.

Table 3

Test for Normality

\begin{tabular}{lll}
\hline & Skewness & Kurtosis \\
\hline Anxiety & -.090 & -.543 \\
Richness & -.268 & -.013 \\
Tolerance & .103 & -.869 \\
Threat & -.240 & -.661 \\
Discrimination & -.814 & .327 \\
\hline Total & .175 & -.065 \\
\hline
\end{tabular}

The data were analysed using SPSS-22 software; the mean, standard deviation, t-test, and one-way analysis of variance test (ANOVA) scores were calculated. In testing the 
Köşker, N., Özgen, N. (2018) Multiculturality concept and its reflections on education: The case of....

differences between group means, the level 0.05 was accepted as significant. For ANOVA, post-hoc (Tukey test, Dunnet $\mathrm{C}$ test) statistics are used to identify the source of the differences between the groups. For the ANOVA, a Tukey test was used in situations where the group variances were homogeneous $(\mathrm{p}>.05)$, and when the group variances were not homogeneous $(\mathrm{p}<0.05)$ according to Levene test results, the Dunnett's C test was applied (Büyüköztürk, 2010, p. 49). In addition, negative items were inverted, so high scores suggest positive attitudes and low scores suggest negative attitudes.

\section{Characteristics of participants}

Table 4

Participants' Ethnic Groups and Their Geographical Distribution

\begin{tabular}{|c|c|c|c|c|c|c|c|c|c|c|c|c|c|c|c|c|}
\hline \multirow[b]{3}{*}{$\begin{array}{l}\text { Geographical } \\
\text { Region }\end{array}$} & \multicolumn{12}{|c|}{ Ethnic Groups } & & & & \\
\hline & \multicolumn{2}{|c|}{ Turkish } & \multicolumn{2}{|c|}{ Kurdish } & \multicolumn{2}{|c|}{ Zaza } & \multicolumn{2}{|c|}{ Circassian } & \multicolumn{2}{|c|}{ Laz } & \multicolumn{2}{|c|}{ Arab } & \multicolumn{2}{|c|}{ OEG* } & \multicolumn{2}{|c|}{ Total } \\
\hline & $\mathbf{n}$ & $\%$ & $\mathbf{n}$ & $\%$ & $\mathbf{n}$ & $\%$ & $\mathbf{n}$ & $\%$ & n & $\%$ & $\mathbf{n}$ & $\%$ & n & $\%$ & $\mathbf{n}$ & $\%$ \\
\hline Marmara & 227 & 85.9 & 10 & 3.7 & 2 & 0.7 & 3 & 1.1 & 4 & 1.5 & 3 & 1.1 & 15 & 5.6 & 264 & 11.8 \\
\hline Aegean & 233 & 83.5 & 18 & 6.4 & 2 & 0.7 & 7 & 2.5 & 10 & 3.5 & 6 & 2.1 & 3 & 1 & 279 & 12.5 \\
\hline Mediterranean & 221 & 82.1 & 34 & 12.6 & 7 & 2.6 & 1 & 0.3 & 3 & 1.1 & 2 & 0.7 & 1 & 0.3 & 269 & 12 \\
\hline $\begin{array}{l}\text { Southeastern } \\
\text { Anatolia }\end{array}$ & 12 & 3.1 & 271 & 70.5 & 31 & 8 & 0 & 0 & 0 & 0 & 69 & 17.9 & 1 & 0.2 & 384 & 17.1 \\
\hline $\begin{array}{l}\text { Eastern } \\
\text { Anatolia }\end{array}$ & 106 & 30.9 & 231 & 67.3 & 1 & 0.2 & 0 & 0 & 1 & 0.3 & 4 & 1.1 & 0 & 0 & 343 & 15.3 \\
\hline Black Sea & 297 & 96.7 & 4 & 1.3 & 0 & 0 & 0 & 0 & 3 & 0.9 & 0 & 0 & 3 & 0.9 & 307 & 13.7 \\
\hline $\begin{array}{l}\text { Central } \\
\text { Anatolia }\end{array}$ & 345 & 88.2 & 32 & 8.1 & 1 & 0.2 & 5 & 1.2 & 4 & 1.3 & 1 & 0.2 & 3 & 0.7 & 391 & 17.5 \\
\hline Total & 1441 & 64.4 & 600 & 26.8 & 44 & 1.9 & 16 & 0.7 & 25 & 1.1 & 85 & 3.8 & 26 & 1.1 & 2237 & 100 \\
\hline
\end{tabular}

Table 4 shows that $64.41 \%$ of the participants were Turkish, $26.82 \%$ were Kurdish, 1.96\% were Zaza, 3.79\% were Arabic, $1.1 \%$ were Laz, 1.1 were OEG (Other Ethnic Groups: Albanians, Azerbaijani, Georgians, Gypsies, Meskhetian, Pomak, Tatar, Uzbek), and $0.7 \%$ were Circassian. It can be seen that $23.94 \%$ of Turkish participants resided in Central Anatolia, 20.61\% in the Black Sea region, 16.16\% in the Aegean region, and $15.75 \%$ in Marmara. Of the Kurdish students, $45.16 \%$ were living in Southeastern Anatolia, 38.5\% in Eastern Anatolia, 5.6\% in the Mediterranean, and 5.3\% in Central Anatolia. Of the Zaza students, $70.45 \%$ were living in Southeastern Anatolia and $15.9 \%$ in the Mediterranean. Of the Arabic students, $81.17 \%$ were living in Southeastern Anatolia. Of the Laz students, $40 \%$ were living in the Aegean. Of the students that belonged to OEG (Other Ethnic Groups), 57.69\% were living in Marmara. Of the Circassian students, $43.75 \%$ were living in the Aegean and $31.25 \%$ in Central Anatolia. 
Table 5

Participants' Monthly Income and Their Geographical Distribution

\begin{tabular}{lcccccccccc}
\hline & \multicolumn{8}{c}{ Family Monthly Income (TL: Turkish Lira)* } \\
\cline { 2 - 11 } Geographical Region & $\begin{array}{c}\text { Lower than } \\
1000\end{array}$ & \multicolumn{2}{c}{ Between } & \multicolumn{2}{c}{ Between } & \multicolumn{2}{c}{ More than } & Total \\
& $\mathbf{n}$ & $\mathbf{\%}$ & $\mathbf{n}$ & $\mathbf{\%}$ & $\mathbf{n}$ & $\mathbf{\%}$ & $\mathbf{n}$ & $\mathbf{\%}$ & $\mathbf{n}$ & $\mathbf{\%}$ \\
\hline Marmara & 37 & 14 & 90 & 34 & 86 & 32.6 & 51 & 19.3 & 264 & 11.8 \\
Aegean & 47 & 16.8 & 87 & 31.1 & 106 & 38 & 39 & 13.9 & 279 & 12.5 \\
Mediterranean & 150 & 55.7 & 75 & 27.8 & 28 & 10.4 & 16 & 5.9 & 269 & 12 \\
Southeastern Anatolia & 251 & 65.3 & 92 & 23.9 & 26 & 6.7 & 15 & 3.9 & 384 & 17.1 \\
Eastern Anatolia & 202 & 58.8 & 52 & 15.1 & 47 & 13.7 & 42 & 12.2 & 343 & 15.3 \\
Black Sea & 54 & 17.5 & 96 & 31.2 & 93 & 30.2 & 64 & 20.8 & 307 & 13.7 \\
Central Anatolia & 42 & 10.7 & 107 & 27.3 & 113 & 28.9 & 129 & 32.9 & 391 & 17.5 \\
\hline Total & 783 & 35 & 599 & 26.7 & 499 & 22.3 & 356 & 15.9 & 2237 & 100 \\
\hline
\end{tabular}

*1 Turkish Lira = 0.19 U.S. dollars in December 2018

As shown in Table 5, 35\% of the participants had 1000TL or less monthly family income. Geographically, $32 \%$ of those with a monthly family income of 1000TL or less came from Southeastern Anatolia and 25.8\% from Eastern Anatolia. Kurds comprised $48.91 \%$ of those with a monthly family income of $1000 \mathrm{TL}$ or less. Of these, $44.12 \%$ were living in Southeastern Anatolia and $46.47 \%$ in Eastern Anatolia. Turks, on the other hand, formed $39.2 \%$ of those with a monthly family income of $1000 \mathrm{TL}$ or less, and $38.43 \%$ of these were living in the Mediterranean. Arabs constituted $7.53 \%$ of those with a monthly family income of 1000TL or less, and $93.22 \%$ of them were living in Southeastern Anatolia. Finally, 3.44\% of those with a monthly family income of 1000TL or less were Zaza, and $77.77 \%$ of them were living in Southeastern Anatolia. Of those with a monthly family income of 3000TL or more, $36.2 \%$ came from Central Anatolia and $17.9 \%$ from the Black Sea region.

Table 6

Participants' Family Education Levels and Their Geographical Distribution

\begin{tabular}{|c|c|c|c|c|c|c|c|c|c|c|c|c|c|c|}
\hline \multirow[b]{3}{*}{$\begin{array}{l}\text { Geographical } \\
\text { Region } \\
\end{array}$} & \multicolumn{14}{|c|}{ Parents' Educational Status (Fat./Father \& Mot./Mother numbers) } \\
\hline & \multicolumn{2}{|c|}{ Illiterate } & \multicolumn{2}{|c|}{ Literate } & \multicolumn{2}{|c|}{$\begin{array}{c}\text { Primary } \\
\text { School }\end{array}$} & \multicolumn{2}{|c|}{$\begin{array}{c}\text { Secondary } \\
\text { School }\end{array}$} & \multicolumn{2}{|c|}{$\begin{array}{l}\text { High } \\
\text { School } \\
\end{array}$} & \multicolumn{2}{|c|}{ University } & \multicolumn{2}{|c|}{$\begin{array}{c}\text { Post- } \\
\text { Graduate }\end{array}$} \\
\hline & Fat. & Mot. & Fat. & Mot. & Fat. & Mot & Fat. & Mot. & Fat. & Mot. & Fat. & Mot. & Fat. & Mot. \\
\hline Marmara & 4 & 10 & 4 & 9 & 46 & 72 & 34 & 48 & 98 & 81 & 63 & 40 & 15 & 4 \\
\hline Aegean & 1 & 5 & 5 & 4 & 41 & 63 & 46 & 51 & 116 & 125 & 61 & 29 & 9 & 2 \\
\hline Mediterranean & 14 & 29 & 2 & 8 & 129 & 147 & 53 & 43 & 56 & 33 & 15 & 9 & 0 & 0 \\
\hline Southeastern Anat. & 51 & 233 & 47 & 42 & 180 & 84 & 55 & 14 & 38 & 7 & 13 & 4 & 0 & 0 \\
\hline Eastern Anatolia & 38 & 153 & 40 & 32 & 99 & 78 & 54 & 34 & 53 & 27 & 48 & 16 & 11 & 3 \\
\hline Black Sea & 0 & 10 & 5 & 16 & 52 & 111 & 71 & 61 & 111 & 78 & 60 & 29 & 8 & 2 \\
\hline Central Anatolia & 2 & 10 & 3 & 3 & 51 & 96 & 59 & 69 & 124 & 130 & 128 & 78 & 24 & 5 \\
\hline
\end{tabular}


Köşker, N., Özgen, N. (2018) Multiculturality concept and its reflections on education: The case of....

As can be seen in Table 6, 46.36\% of participants whose fathers were illiterate were living in Southeastern Anatolia and 34.54\% of them in Eastern Anatolia. By the same token, $44.33 \%$ of participants whose fathers were literate were living in Southeastern Anatolia and $37.73 \%$ in Eastern Anatolia. On the other hand, 32.98\% of participants whose fathers were university graduates were living in Central Anatolia, while $35.82 \%$ of participants whose fathers had a graduate degree were living in Central Anatolia and $22.38 \%$ of them in Marmara.

Regarding mothers, $51.77 \%$ of participants whose mothers were illiterate were living in Southeastern Anatolia and 34\% in Eastern Anatolia. Similarly, 36.84\% of participants whose mothers were literate were living in Southeastern Anatolia and 28.07\% in Eastern Anatolia. Of those whose mothers were university graduates, $38.04 \%$ were living in Central Anatolia and $19.51 \%$ in the Marmara region. On the other hand, $31.25 \%$ of participants whose mothers held a graduate degree were living in Central Anatolia and $25 \%$ in the Marmara region.

\section{Findings}

Findings about the analysis of participants' multiculturality attitudes are tabulated below and interpreted:

Table 7

Analysis of the Multiculturality Attitudes of Students Based on Their Gender (t-test)

\begin{tabular}{|c|c|c|c|c|c|c|}
\hline Dimensions & Gender & $\mathbf{N}$ & $\bar{x}$ & Sd & $\mathbf{t}$ & p \\
\hline \multirow{2}{*}{ Anxiety } & Female & 1291 & 22.0132 & 4.39986 & \multirow{2}{*}{11.567} & \multirow{2}{*}{.000} \\
\hline & Male & 946 & 19.6913 & 4.89183 & & \\
\hline \multirow{2}{*}{ Richness } & Female & 1291 & 18.4423 & 3.49090 & \multirow{2}{*}{1.106} & \multirow{2}{*}{.269} \\
\hline & Male & 946 & 18.2622 & 4.01992 & & \\
\hline \multirow{2}{*}{ Tolerance } & Female & 1291 & 8.7653 & 3.43623 & \multirow{2}{*}{7.214} & \multirow{2}{*}{.000} \\
\hline & Male & 946 & 7.6765 & 3.59085 & & \\
\hline \multirow{2}{*}{ Threat } & Female & 1291 & 13.9543 & 3.91225 & \multirow{2}{*}{5.234} & \multirow{2}{*}{.000} \\
\hline & Male & 946 & 13.0486 & 4.13602 & & \\
\hline \multirow{2}{*}{ Discrimination } & Female & 1291 & 12.6778 & 2.32378 & \multirow{2}{*}{7.046} & \multirow{2}{*}{.000} \\
\hline & Male & 946 & 11.9260 & 2.60988 & & \\
\hline \multirow{2}{*}{ Total } & Female & 1291 & 75.8528 & 10.95502 & \multirow{2}{*}{10.675} & \multirow{2}{*}{.000} \\
\hline & Male & 946 & 70.6047 & 11.86137 & & \\
\hline
\end{tabular}

Table 7 shows that the multiculturality attitudes of the male and female students in the anxiety, tolerance, threat and discrimination dimensions and in the overall scale show a significant difference in favour of females $(p<0.05)$. In the richness dimension, no significant difference based on gender can be seen $(p>0.05)$; however, in this dimension, female students have higher mean scores of attitude compared to male students. This finding demonstrates that female students' multiculturality attitudes were more positive than those of male students. 
Table 8

Analysis of the Multiculturality Attitudes of the Students Based on Their Class Level

\begin{tabular}{|c|c|c|c|c|c|c|c|}
\hline Dimensions & $\begin{array}{c}\text { The Source of } \\
\text { Variance }\end{array}$ & $\begin{array}{l}\text { Sum of } \\
\text { Squares }\end{array}$ & df & $\begin{array}{c}\text { Mean } \\
\text { Square }\end{array}$ & $\mathbf{F}$ & $\mathbf{p}$ & $\begin{array}{l}\text { Significant } \\
\text { Difference }\end{array}$ \\
\hline \multirow{3}{*}{ Anxiety } & Between Groups & 448.752 & 2 & 224.376 & \multirow{3}{*}{10.009} & \multirow{3}{*}{.000} & $12^{\text {th }}>10^{\text {th }}$ \\
\hline & Within Groups & 50081.057 & 2234 & 22.418 & & & $12^{\text {th }}>11^{\text {th }}$ \\
\hline & Total & 50529.810 & 2236 & & & & \\
\hline \multirow{3}{*}{ Richness } & Between Groups & 409.624 & 2 & 204.812 & \multirow{3}{*}{14.953} & \multirow{3}{*}{.000} & $11^{\text {th }}>10^{\text {th }}$ \\
\hline & Within Groups & 30599.528 & 2234 & 13.697 & & & $12^{\text {th }}>10^{\text {th }}$ \\
\hline & Total & 31009.152 & 2236 & & & & $12^{\text {th }}>11^{\text {th }}$ \\
\hline \multirow{3}{*}{ Tolerance } & Between Groups & 21.024 & 2 & 10.512 & \multirow{3}{*}{.837} & \multirow{3}{*}{.433} & \multirow{3}{*}{$\begin{array}{c}\text { No } \\
\text { difference }\end{array}$} \\
\hline & Within Groups & 28043.053 & 2234 & 12.553 & & & \\
\hline & Total & 28064.077 & 2236 & & & & \\
\hline \multirow{3}{*}{ Threat } & Between Groups & 566.695 & 2 & 283.348 & \multirow{3}{*}{17.686} & \multirow{3}{*}{.000} & $11^{\text {th }}>10^{\text {th }}$ \\
\hline & Within Groups & 35791.182 & 2234 & 16.021 & & & $11^{\text {th }}>12^{\text {th }}$ \\
\hline & Total & 36357.878 & 2236 & & & & $12^{\text {th }}>10^{\text {th }}$ \\
\hline \multirow{3}{*}{ Discrimination } & Between Groups & 73.248 & 2 & 36.624 & \multirow{3}{*}{5.999} & \multirow{3}{*}{.003} & $12^{\text {th }}>11^{\text {th }}$ \\
\hline & Within Groups & 13638.067 & 2234 & 6.105 & & & \\
\hline & Total & 13711.315 & 2236 & & & & \\
\hline \multirow{3}{*}{ Total } & Between Groups & 3172.397 & 2 & 1586.199 & \multirow{3}{*}{11.826} & \multirow{3}{*}{.000} & $11^{\text {th }}>10^{\text {th }}$ \\
\hline & Within Groups & 299635.022 & 2234 & 134.125 & & & $12^{\text {th }}>10^{\text {th }}$ \\
\hline & Total & 302807.419 & 2236 & & & & $12^{\text {th }}>11^{\text {th }}$ \\
\hline
\end{tabular}

Notes: Significant Difference column identifies the source of the differences between the groups.

According to the ANOVA results in Table 8, the participants' multiculturality attitudes in the anxiety, richness, threat, and discrimination dimensions were significant based on the class level of the variable $(p<0.05)$. However, in the multiculturality attitudes of the students, no statistically significant relationship existed between the dimension of tolerance and the participants' class level $(p>0.05)$. The results of the analysis indicate that the attitude mean scores among $12^{\text {th }}$ graders in the anxiety, richness, tolerance, and discrimination dimensions were higher $(\bar{X}=21.8127 ; \bar{X}=$ $19.0073 ; \bar{X}=8.4564$ and $\bar{X}=12.6327$, respectively).

The attitude mean scores of the $11^{\text {th }}$ graders were higher in the threat dimension compared to other students. Meanwhile, the attitude mean scores of the $10^{\text {th }}$ graders were low in anxiety, richness, and threat dimensions $(\bar{X}=20.7233 ; \bar{X}=17.8545$ and $\bar{X}$ $=12.9101$; respectively) and the attitude mean scores of the $11^{\text {th }}$ graders were low in discrimination dimension $(\bar{X}=12.1815)$. However, in the overall evaluation of the scale, the attitude mean scores of the $12^{\text {th }}$ and $11^{\text {th }}$ graders $(\bar{X}=75.4073$ and $\bar{X}=73.6633$, respectively) were higher while the attitude mean scores of the $10^{\text {th }}$ graders were lower $(\bar{X}=72.1997)$. 
Köşker, N., Özgen, N. (2018) Multiculturality concept and its reflections on education: The case of....

Table 9

Analysis of the Multiculturality Attitudes of the Students Based on Their Monthly Family Income

\begin{tabular}{|c|c|c|c|c|c|c|c|}
\hline Dimensions & $\begin{array}{c}\text { The Source of } \\
\text { Variance }\end{array}$ & $\begin{array}{l}\text { Sum of } \\
\text { Squares }\end{array}$ & df & $\begin{array}{c}\text { Mean } \\
\text { Square }\end{array}$ & $\mathbf{F}$ & $\mathbf{p}$ & $\begin{array}{l}\text { Significant } \\
\text { Difference }\end{array}$ \\
\hline \multirow{3}{*}{ Anxiety } & Between Groups & 1683.195 & 3 & 561.065 & \multirow{3}{*}{25.649} & \multirow{3}{*}{.000} & $2>1 ; 3>1$ \\
\hline & Within Groups & 48846.614 & 2233 & 21.875 & & & $4>1 ; 4>2$ \\
\hline & Total & 50529.810 & 2236 & & & & $4>3$ \\
\hline \multirow{3}{*}{ Richness } & Between Groups & 142.590 & 3 & 47.530 & \multirow{3}{*}{3.438} & \multirow{3}{*}{.016} & \multirow{3}{*}{$4>2$} \\
\hline & Within Groups & 30866.562 & 2233 & 13.823 & & & \\
\hline & Total & 31009.152 & 2236 & & & & \\
\hline \multirow{3}{*}{ Tolerance } & Between Groups & 921.344 & 3 & 307.115 & \multirow{3}{*}{25.266} & \multirow{3}{*}{.000} & $3>1 ; 3>2$ \\
\hline & Within Groups & 27142.732 & 2233 & 12.155 & & & $4>1 ; 4>2$ \\
\hline & Total & 28064.077 & 2236 & & & & \\
\hline \multirow{3}{*}{ Threat } & Between Groups & 1876.900 & 3 & 625.633 & \multirow{3}{*}{40.516} & \multirow{3}{*}{.000} & $1>2 ; 1>3$ \\
\hline & Within Groups & 34480.977 & 2233 & 15.442 & & & $1>4 ; 2>4$ \\
\hline & Total & 36357.878 & 2236 & & & & \\
\hline \multirow{3}{*}{ Discrimination } & Between Groups & 86.964 & 3 & 28.988 & \multirow{3}{*}{4.751} & \multirow{3}{*}{.003} & \multirow{3}{*}{$4>1$} \\
\hline & Within Groups & 13624.351 & 2233 & 6.101 & & & \\
\hline & Total & 13711.315 & 2236 & & & & \\
\hline \multirow{3}{*}{ Total } & Between Groups & 3448.676 & 3 & 1149.559 & \multirow{3}{*}{8.575} & \multirow{3}{*}{.000} & \multirow{3}{*}{$\begin{array}{c}4>1 ; 4>2 \\
4>3\end{array}$} \\
\hline & Within Groups & 299358.743 & 2233 & 134.061 & & & \\
\hline & Total & 302807.419 & 2236 & 561.065 & & & \\
\hline
\end{tabular}

1: Lower than 1000 TL 2: Between 1001-2000 TL 3: Between 2001-3000 TL 4: More than $3000 \mathrm{TL}$ Notes: Significant Difference column identifies the source of the differences between the groups.

The participants' multiculturality attitudes showed statistically significant differences $(p<0.05)$ based on family income in all dimensions and in the overall scale (Table 9). In the evaluation of participants' multiculturality attitudes, the attitude mean scores of students whose family incomes were higher than 3000 TL were higher $(\bar{X}=22.7809, \bar{X}$ $=18.8876, \bar{X}=9.4607$ and $\bar{X}=12.7331$, respectively) in the dimensions of anxiety, richness, tolerance, and discrimination. Furthermore, the attitude mean scores of the students whose family incomes were lower than $1000 \mathrm{TL}$ were high in the threat dimension $(\bar{X}=14.7803)$. The attitude mean scores of the students whose family income was lower than $1000 \mathrm{TL}$ were low in the anxiety, discrimination, and tolerance dimensions $(\bar{X}=20.1916, \bar{X}=12.1622$ and $\bar{X}=7.7905$, respectively). In addition, the attitude mean scores of the students whose family incomes were between 1001 and 2000 TL were low $(\bar{X}=18.0985)$ in the richness dimension while those of the students whose family had an income of more than $3000 \mathrm{TL}$ were low $(\bar{X}=12.4663)$ in the threat dimension. According to total score of the scale, the attitude mean scores of students whose family income was more than $3000 \mathrm{TL}$, between 2001 and $3000 \mathrm{TL}$, and lower than $1000 \mathrm{TL}$ were high $(\bar{X}=76.3287 ; \bar{X}=73.5932$ and $\bar{X}=73.3052$, respectively) whereas those of the students with family incomes ranging between 1001 and 2000 TL were low $(\bar{X}=72.4942)$. 
Table 10

Analysis of the Multiculturality Attitudes of the Students Based on Their Father's Educational Status

\begin{tabular}{|c|c|c|c|c|c|c|c|}
\hline Dimensions & $\begin{array}{l}\text { The Source of } \\
\text { Variance }\end{array}$ & $\begin{array}{c}\text { Sum of } \\
\text { Squares } \\
\end{array}$ & df & $\begin{array}{c}\text { Mean } \\
\text { Square }\end{array}$ & $\mathbf{F}$ & $\mathbf{p}$ & $\begin{array}{l}\text { Significant } \\
\text { Difference } \\
\end{array}$ \\
\hline \multirow{6}{*}{ Anxiety } & Between Groups & 1657.175 & 6 & 276.196 & 12.602 & .000 & $3>1 ; 4>1$ \\
\hline & Within Groups & 48872.635 & 2230 & 21.916 & & & $5>1 ; 6>1$ \\
\hline & Total & 50529.810 & 2236 & & & & $6>2 ; 6>3$ \\
\hline & & & & & & & $6>4 ; 7>1$ \\
\hline & & & & & & & $7>2 ; 7>3$ \\
\hline & & & & & & & $7>4 ; 7>5$ \\
\hline \multirow{3}{*}{ Richness } & Between Groups & 319.657 & 6 & 53.276 & 3.871 & .001 & \multirow{3}{*}{$2>3 ; 2>4$} \\
\hline & Within Groups & 30689.494 & 2230 & 13.762 & & & \\
\hline & Total & 31009.152 & 2236 & & & & \\
\hline \multirow{3}{*}{ Tolerance } & Between Groups & 847.817 & 6 & 141.303 & \multirow[t]{3}{*}{11.578} & .000 & \multirow{3}{*}{$\begin{array}{l}5>3 ; 5>4 ; \\
6>1 ; 6>3 \\
6>4 ; 6>5 \\
7>3 ; 7>4\end{array}$} \\
\hline & Within Groups & 27216.260 & 2230 & 12.205 & & & \\
\hline & Total & 28064.077 & 2236 & & & & \\
\hline \multirow{6}{*}{ Threat } & Between Groups & 1823.369 & 6 & 303.895 & \multirow[t]{6}{*}{19.623} & .000 & \multirow{6}{*}{$\begin{array}{l}1>3 ; 1>4 ; \\
1>5 ; 1>6 ; \\
1>7 ; 2>4 ; \\
2>5 ; 2>6 ; \\
2>7 ; 3>5 ; \\
3>6 ; 3>7 ; \\
4>6 ; 4>7\end{array}$} \\
\hline & Within Groups & 34534.508 & 2230 & 15.486 & & & \\
\hline & Total & 36357.878 & 2236 & & & & \\
\hline & & & & & & & \\
\hline & & & & & & & \\
\hline & & & & & & & \\
\hline \multirow{3}{*}{ Discrimination } & Between Groups & 169.699 & 6 & 28.283 & \multirow[t]{3}{*}{4.658} & .000 & \multirow{3}{*}{$\begin{array}{c}3>1 ; 4>1 ; \\
5>1 ; \\
6>1 ; 7>1\end{array}$} \\
\hline & Within Groups & 13541.617 & 2230 & 6.072 & & & \\
\hline & Total & 13711.315 & 2236 & & & & \\
\hline \multirow{3}{*}{ Total } & Between Groups & 2512.519 & 6 & 418.753 & \multirow[t]{3}{*}{3.110} & .005 & \multirow{3}{*}{$6>4$} \\
\hline & Within Groups & 300294.900 & 2230 & 134.661 & & & \\
\hline & Total & 302807.419 & 2236 & & & & \\
\hline
\end{tabular}

1:Illiterate, 2:Literate, 3:Primary School, 4:Secondary School, 5:High School, 6:University, 7:Post-Graduate Notes: Significant Difference column identifies the source of the differences between the groups.

Table 10 reveals that participants' multiculturality attitudes showed statistically significant differences $(p<0.05)$ based on the father's educational status in all dimensions as well as in the overall scale. In the evaluation of the dimensions, the attitude mean scores of those students whose fathers had a postgraduate degree were higher in the anxiety and tolerance dimensions $(\bar{X}=23.6119$ and $\bar{X}=9.7910$, respectively) than the other students. Similarly, the attitude mean scores of those whose fathers are literate were higher $(\bar{X}=19.4811)$ in the richness dimension, the scores of those whose fathers are illiterate were higher $(\bar{X}=15.5909)$ in the threat dimension, and the scores of those whose fathers have a university degree were also higher $(\bar{X}$ $=12.6134)$ in the discrimination dimension than the other students' attitude mean scores. The attitude mean scores of students whose fathers are illiterate were low in the anxiety and discrimination dimensions $(\bar{X}=18.8000$ and $\bar{X}=11.2818$, respectively) while the scores of those whose fathers are secondary school graduates were low $(\bar{X}=17.9032)$ in the richness dimension. Similarly, the attitude mean scores of the students whose fathers are primary school graduates were low $(\bar{X}=7.6773)$ in the tolerance dimension and those with fathers having a postgraduate degree were low $(\bar{X}=11.7313)$ in the threat 
dimension. The analysis based on father's educational status variable demonstrated that the attitude mean scores of the students whose fathers are university graduates were higher $(\bar{X}=75.0541)$ than those of whose fathers have a secondary school degree $(\bar{X}=$ 72.5591).

Table 11

Analysis of the Multiculturality Attitudes of the Students Based on Their Mother's Educational Status

\begin{tabular}{|c|c|c|c|c|c|c|c|}
\hline Dimensions & $\begin{array}{c}\text { The Source of } \\
\text { Variance }\end{array}$ & $\begin{array}{l}\text { Sum of } \\
\text { Squares }\end{array}$ & df & $\begin{array}{c}\text { Mean } \\
\text { Square }\end{array}$ & $\mathbf{F}$ & $\mathbf{p}$ & $\begin{array}{l}\text { Significant } \\
\text { Difference }\end{array}$ \\
\hline \multirow{3}{*}{ Anxiety } & Between Groups & 2020.787 & 6 & 336.798 & \multirow[t]{3}{*}{15.483} & \multirow[t]{3}{*}{.000} & $3>1 ; 4>1$ \\
\hline & Within Groups & 48509.023 & 2230 & 21.753 & & & $5>1 ; 6>1$ \\
\hline & Total & 50529.810 & 2236 & & & & $\begin{array}{l}6>2 ; 6>3 \\
6>4 ; 6>5\end{array}$ \\
\hline \multirow{3}{*}{ Richness } & Between Groups & 430.046 & 6 & 71.674 & \multirow[t]{3}{*}{5.227} & \multirow[t]{3}{*}{.000} & \\
\hline & Within Groups & 30579.105 & 2230 & 13,713 & & & $\begin{array}{l}1>4 ; 2>3 ; \\
2>4 \cdot 6>4\end{array}$ \\
\hline & Total & 31009.152 & 2236 & & & & \\
\hline \multirow{4}{*}{ Tolerance } & Between Groups & 1934.942 & 6 & 322.490 & \multirow[t]{4}{*}{27.523} & \multirow[t]{4}{*}{.000} & $5>1 ; 5>2$ \\
\hline & Within Groups & 26129.135 & 2230 & 11.717 & & & $5>3 ; 5>4$ \\
\hline & Total & 28064.077 & 2236 & & & & $6>1 ; 6>2$ \\
\hline & & & & & & & $\begin{array}{l}6>3 ; 6>4 ; \\
7>1 ; 7>2 \\
7>3 ; 7>4\end{array}$ \\
\hline \multirow{5}{*}{ Threat } & Between Groups & 3737.976 & 6 & 622.996 & \multirow[t]{5}{*}{42.590} & \multirow[t]{5}{*}{.000} & $1>3 ; 1>4$ \\
\hline & Within Groups & 32619.902 & 2230 & 14.628 & & & $1>5 ; 1>6$ \\
\hline & Total & 36357.878 & 2236 & & & & $1>7 ; 2>3$ \\
\hline & & & & & & & $2>4 ; 2>5$ \\
\hline & & & & & & & $\begin{array}{l}2>6 ; 2>7 \\
3>4 ; 3>5\end{array}$ \\
\hline \multirow{3}{*}{ Discrimination } & Between Groups & 339.441 & 6 & 56.573 & \multirow[t]{3}{*}{9.435} & \multirow[t]{3}{*}{.000} & $3>1 ; 4>1 ;$ \\
\hline & Within Groups & 13371.874 & 2230 & 5.996 & & & $5>1$ \\
\hline & Total & 13711.315 & 2236 & & & & $6>1 ; 6>5$ \\
\hline \multirow{3}{*}{ Total } & Between Groups & 7055.274 & 6 & 1175.879 & \multirow[t]{3}{*}{8.866} & \multirow[t]{3}{*}{.000} & $1>4 ; 2>4$ \\
\hline & Within Groups & 295752.145 & 2230 & 132.624 & & & $5>4 ; 6>1$ \\
\hline & Total & 302807.419 & 2236 & & & & $\begin{array}{c}6>3 ; 6>4 \\
6>5\end{array}$ \\
\hline
\end{tabular}

1: Illiterate, 2:Literate, 3:Primary School, 4:Secondary School, 5:High School, 6:University, 7: Post-Graduate

Notes: Significant Difference column identifies the source of the differences between the groups.

Table 11 showed statistically significant differences $(p<0.05)$ in multiculturality attitudes of high school students based on their mother's educational status in all dimensions and the overall scale. In the analysis of the dimensions, the attitude mean scores of the students whose mothers have a university degree were higher in the anxiety and discrimination dimensions $(\bar{X}=23.4000$ and $\bar{X}=12.9805$, respectively) than the other students; those whose mothers are literate had a higher score $(\bar{X}$ $=19.2632$ ) in richness dimension than other students. In addition, the attitude mean scores of the students whose mothers have a postgraduate degree were higher $(\bar{X}=$ 11.6250) in the tolerance dimension, and students with mothers who are illiterate had a higher score $(\bar{X}=15.7156)$ in the threat dimension than the other students. 
The calculation of the attitude mean scores of participants whose mothers are illiterate were lower, with $\bar{X}=19.8089$ and $\bar{X}=11.6978$ for the anxiety and discrimination dimensions, respectively. Meanwhile, scores of participants whose mothers are secondary school graduates were lower in the richness and tolerance dimensions $(\bar{X}=18.1290$ and $\bar{X}=7.5469$, respectively). Finally, the scores of those whose mothers have postgraduate degrees were lower $(\bar{X}=10.6250)$ in the threat dimension.

The total score of the scale revealed that students with mothers in the university graduate, literate, and postgraduate categories had higher attitude mean scores, with $\bar{X}$ $=77.7707 ; \bar{X}=75.3947$ and $\bar{X}=75.2500$, respectively. However, the attitude mean scores of those whose mothers are primary and secondary school graduates were lower $(\bar{X}=72.7143$ and $\bar{X}=70.8906$, respectively).

Table 12

Analysis of the Multiculturality Attitudes of the Students Based on Geographic Regions

\begin{tabular}{|c|c|c|c|c|c|c|c|}
\hline Dimensions & $\begin{array}{c}\text { The Source of } \\
\text { Variance }\end{array}$ & $\begin{array}{r}\text { Sum of } \\
\text { Squares }\end{array}$ & df & $\begin{array}{c}\text { Mean } \\
\text { Square }\end{array}$ & $\mathbf{F}$ & $\mathbf{p}$ & $\begin{array}{l}\text { Significant } \\
\text { Difference }\end{array}$ \\
\hline \multirow[b]{3}{*}{ Anxiety } & Between Groups & 4735.193 & 6 & 789.199 & \multirow{3}{*}{38.431} & \multirow{3}{*}{.000} & $1>2 ; 1>4 ; 1>5$ \\
\hline & Within Groups & 45794.617 & 2230 & 20.536 & & & $3>2 ; 3>4 ; 3>5$ \\
\hline & Total & 50529.810 & 2236 & & & & $\begin{array}{c}6>2 ; 6>4 ; 6>5 ; \\
7>2 ; 7>4 ; 7>5 ; \\
7>6\end{array}$ \\
\hline \multirow[b]{3}{*}{ Richness } & Between Groups & 1565.762 & 6 & 260.960 & \multirow{3}{*}{19.765} & \multirow{3}{*}{.000} & $1>2 ; 1>3 ; 1>5$ \\
\hline & Within Groups & 29443.389 & 2230 & 13.203 & & & $3>2 ; 4>2 ; 4>3$ \\
\hline & Total & 31009.152 & 2236 & & & & $\begin{array}{c}4>5 ; 4>6 ; 4>7 \\
5>2 ; 6>2 ; 7>2 ; \\
7>5 ;\end{array}$ \\
\hline \multirow{4}{*}{ Tolerance } & Between Groups & 1609.756 & 6 & 268.293 & \multirow{4}{*}{22.616} & \multirow{4}{*}{.000} & $1>3 ; 1>4 ; 2>3$ \\
\hline & Within Groups & 26454.321 & 2230 & 11.863 & & & $2>4 ; 2>6 ; 5>3$ \\
\hline & Total & 28064.077 & 2236 & & & & $5>4 ; 5>6 ; 6>3$ \\
\hline & & & & & & & $\begin{array}{c}7>1 ; 7>3 ; 7>4 \\
\quad 7>5 ; 7>6\end{array}$ \\
\hline \multirow{4}{*}{ Threat } & Between Groups & 3897.650 & 6 & 649.608 & \multirow{4}{*}{44.628} & \multirow{4}{*}{.000} & $1>2 ; 3>2 ; 4>1$ \\
\hline & Within Groups & 32460.228 & 2230 & 14.556 & & & $4>2 ; 4>3 ; 4>5$ \\
\hline & Total & 36357,878 & 2236 & & & & $4>6 ; 4>7 ; 5>1$ \\
\hline & & & & & & & $\begin{array}{c}5>2 ; 5>3 ; 5>6 \\
5>7 ; 7>2\end{array}$ \\
\hline \multirow{4}{*}{ Discrimination } & Between Groups & 1478.893 & 6 & 246.482 & \multirow{4}{*}{44.934} & \multirow{4}{*}{.000} & $2>1 ; 2>5 ; 3>1 ;$ \\
\hline & Within Groups & 12232.422 & 2230 & 5.485 & & & $3>2 ; 3>4 ; 3>5$ \\
\hline & Total & 13711.315 & 2236 & & & & $4>1 ; 4>5 ; 6>1 ;$ \\
\hline & & & & & & & $\begin{array}{l}6>2 ; 6>4 ; 6>5 ; \\
7>1 ; 7>2 ; 7>5\end{array}$ \\
\hline \multirow{3}{*}{ Total } & Between Groups & 12639.758 & 6 & 2106.626 & \multirow{3}{*}{16.190} & \multirow{3}{*}{.000} & $1>2 ; 1>5 ; 3>2 ;$ \\
\hline & Within Groups & 290167.661 & 2230 & 130.120 & & & $4>2 ; 4>5 ; 5>2$ \\
\hline & Total & 302807.419 & 2236 & & & & $\begin{array}{c}6>2 ; 7>2 ; 7>3 ; \\
\quad 7>5 ; 7>6\end{array}$ \\
\hline
\end{tabular}

1: Marmara region, 2: Aegean region, 3: Mediterranean region, 4: Southeastern Anatolia region,

5: Eastern Anatolia region, 6: Black Sea region, 7: Central Anatolia region

Notes: Significant Difference column identifies the source of the differences between the groups. 
Finally, as seen in Table 12, participants' multiculturality attitudes showed statistically significant differences $(p<0.05)$ based on the region of residence in all dimensions and the overall scale. Accordingly, the attitude mean scores of the students who live in the Central Anatolia Region were higher in anxiety and tolerance dimensions ( $\bar{X}=22.8824$ and $\bar{X}=9.5064$, respectively) than the other students, and those who live in Southeastern Anatolia had higher scores in richness and threat dimensions $(\bar{X}=19.6406$ and $\bar{X}=15.7708$, respectively) than other students. Furthermore, the participants who live in the Mediterranean and Black Sea Regions had higher attitude mean scores in the discrimination dimension $(\bar{X}=13.3457$ and $\bar{X}$ $=13.2736$ ) than those who live in other regions.

The attitude mean scores of the students living in the Aegean Region were lower in the anxiety, richness, and threat dimensions $(\bar{X}=18.9283 ; \bar{X}=16.8817$, and $\bar{X}=11.8280$, respectively) compared to the students living in other regions. Similarly, the participants from the Mediterranean Region had the lowest attitude mean scores for the tolerance dimension $(\bar{X}=6.8550)$ while the participants from the Eastern Anatolia Region had the lowest attitude mean scores in the discrimination dimension $(\bar{X}=11.0117)$.

The total score of the scale indicated that participants' attitude mean scores showed statistically significant differences based on the geographic region of residence. Compared with students from other regions, participants from the Central Anatolia Region, Southeastern Anatolia, and Marmara Region had higher attitude mean scores $(\bar{X}$ $=76.7263 ; \bar{X}=74.9609 ; \bar{X}=74.9242$, respectively) whereas those in Aegean Region had the lowest attitude mean scores $(\bar{X}=68.6918)$.

\section{Results and Discussion}

Students' multiculturality attitudes showed significant differences based on variables such as gender, class level, family income, parents' educational status, and geographic region. The findings indicated that the female students' attitude mean scores were more positive than those of the male students. Cansabuncu (2008) similarly concluded that female high school students' attitudes towards ethnic and religious differences were more positive than those of male students. In research conducted by Uydaş and Genç (2015), in the context of global citizenship, female high school students' views towards multiculturality were more positive than those of the male students. In the research area oriented towards multiculturality, many studies have been conducted with different sampling groups based on different characteristics such as democratic attitudes, sexual orientation, social gender roles, and disability. Such studies have shown similar results in terms of the gender variable as the current study (Atış, 2010; PMAPD/Prime Ministry Administration of Persons with Disabilities, 1997; Çalışkan \& Sağlam, 2012; Çoban, Karaman \& Doğan, 2010; Çolak, 2009; Engstrom \& Sedlacek, 1997; Gömleksiz \& Çetintaş, 2011; İlğan, Karayiğit \& Çetin, 2013; Yılmaz et al., 2009). According to Gilligan (1977), women's experiences differ from men's in terms of quality; in addition, their emotions and feelings affect their decisions and relationships with others. Therefore, being responsible and considerate forms the main theme supporting their moral decisions (as cited in Bondi, Heasley, Kolko and Young, 2003). In this sense, in 
students' multiculturality attitudes, the reason for the difference based on gender might be the result of girls having different affective and cognitive attitudes than boys. Various research results revealed that women's empathic tendencies were higher than those of men (Arslan, 2016; Hasta \& Güler, 2013). This situation can be interpreted as such: women who are considered to be "other" in male-dominated society are more empathetic and tolerant towards other people.

In students' multiculturality attitudes, significant differences based on the grade level variable were found in all of the dimensions except Tolerance. The evaluation of the dimensions and the overall scale indicated that the multiculturality attitude scores of the $12^{\text {th }}$ and $11^{\text {th }}$ graders were higher than those of the $10^{\text {th }}$ graders. In the Tolerance dimension, which focuses on the attitudes towards people whose sexual orientations are different, no significant differences were found among students' different class levels. However, the $12^{\text {th }}$ graders obtained higher scores than students in other class levels students, which might be explained by the fact that, as students' length of education and age increase, their attitudes towards multiculturality change in a positive way.

Students' multiculturality attitudes based on their family income level showed significant differences in all dimensions and the overall scale. Students whose family income levels were greater than 3000 TL had higher attitude mean scores in the Anxiety, Richness, Tolerance, and Discrimination dimensions, yet the scores of those with a family income lower than 1000 TL were higher in the Threat dimension. Participants whose family incomes are greater than 3000 TL had the lowest mean score in the Threat dimension when compared to the other income level groups; such a finding might be interpreted as those students who have high levels of family income have more negative attitudes towards the Threat dimension. In other words, it was detected that the students who have high family income regard multiculturality as a threat. Cansabuncu (2008) found that students from families with a high level of income worry about the demands of the ethnic groups more than those from families with a low level of income. Likewise, in a study conducted by Gömleksiz and Çetintaş (2011), university students whose family income was in the low and middle levels had a more positive democratic attitude than those with higher levels of family income. As the income level increases, individuals establish their living space away from social contact. In particular, migrant individuals from different ethnic groups can become a threat leading up to social tension. Çakırer (2006) states that the migration of poor and ethnic minorities to the city is perceived by the affluent class as the siege of cities and that such people from elite class have the intention to escape from the besieged city and to move away from all the misdeeds of the city. Therefore, the multidimensional exclusion policies of the nationstate as well as the urban transformation efforts of neoliberal urban policies in the cities receiving immigration conduce to the creation of new areas of exclusion/stigmatization related to ethnic, religious, racial, and poverty-related affiliations (Aytaç, 2016).

In terms of parental education, significant differences were evident in students' multiculturality attitudes in all dimensions and the overall scale. In the Richness dimension, students who had literate parents had the highest scores. In terms of Anxiety, Tolerance, and Discrimination, students whose parents had undergraduate and postgraduate degrees indicated higher mean scores of attitude. Another remarkable 
finding was that the students who had illiterate parents scored higher in the Threat dimension. The fact that the highest scores in this dimension belong to students whose mothers had a postgraduate degree or fathers had graduate and postgraduate degrees suggests that, in Turkey, an increase in a person's education level does not appear to have a positive impact on the individual in terms of multiculturality; indeed, increasing the level of education seems to trigger negatives towards "others" and create discrimination. Similarly, Gömleksiz and Çetintaş (2011) concluded that the university students whose mothers are illiterate have a more positive democratic attitude than students whose mothers have completed primary school or more. Moreover, university students whose mothers were university graduates had lower democratic attitude scores. Baker's (2013, p.62) definition "schools carve individuals on behalf of the society" also represents this pattern. Such socio-cultural and behavioral approaches deepen the political aims of the ruling elite regarding education, give its own legitimacy a systematic structure, and make its own ideological existence continuous. Therefore, both ideology and the education system are reduced to the imposition of these principles on the society. Schools shoulder the function of teaching the norms, values and culture that contribute to the ideological hegemony of the dominant groups (Apple, 2012, p.85). Therefore, schools not only create an effective and dominant culture, but also assume the position of an important tool in the process of reproducing culture.

Students' attitudes towards multiculturality based on their geographic residence showed significant differences in all dimensions and the overall scale. Students in Central Anatolia, Southeastern Anatolia and Marmara regions had higher attitude scores than students from other regions. Especially in Southeastern Anatolia, where different cultural forms exist and cultural differences have been maintained for centuries, people develop positive attitudes towards those differences. Similarly, in cities in the Central Anatolia and Marmara regions, such as Bursa, Ankara, and Kırşehir, students have positive attitudes towards multiculturality that are thought to emanate from encountering people from different cultures resulting from mass immigration from other cities and living close to the immigrants. Interestingly, students in the Aegean region scored lower than students from other regions. As these participants were selected from high schools in Izmir, it can be concluded that nationalist and political stances were reflected in participants' attitudes. Thus, it can be concluded that individuals are nurtured by the cultural values of the regions in which they live and they develop attitudes accordingly. As a result, the differences in students' attitudes can be explained by economic, cultural, and socio-political characteristics of the location. Indeed, Saraçoğlu (2009) also found in his study that the middle class in Izmir had high ethnic threat perceptions and anxiety.

The important findings of the study may be summarized as follows:

- In all the dimensions of the scale (i.e., anxiety, richness, tolerance, threat, and discrimination), female students showed higher attitude scores (more positive attitudes) than male students.

- As students' progress in school (i.e., increase grade level), their multiculturality attitude scores usually increase. 
- As students' family income level increases, they regard multiculturality as a threat (ethnicity-based). Students with a low monthly family income (largely residing in Southeastern and Eastern Anatolia) are more positive than others in the threat dimension and create a significant difference.

- Students whose parents have a high level of education regard multiculturality as a threat (ethnicity-based). At the same time, students with a higher family income level were found to experience lower anxiety levels, perceive multiculturality as richness despite a high perception of threat, and have higher tolerance levels.

- Students with a high family income level have more positive attitudes towards disadvantaged groups, such as women and the disabled.

- Students whose parents are illiterate have low scores on the anxiety (nationalist -conservative based) and discrimination (more negative towards disadvantaged groups) dimensions.

- Students whose parents are illiterate and are not illiterate (residing largely in Southeastern and Eastern Anatolia) have more positive attitudes in the Threat dimension and create a significant difference.

- The discrimination (more negative towards disadvantaged groups) attitude scores of the students in Eastern Anatolia are lower.

- Students living in the Aegean region regard multiculturality as a threat (ethnicity-based) and have high levels of anxiety (nationalist-conservative based) concerning this item.

- Participants from the Mediterranean region have a lower level of tolerance towards people whose sexual orientations differ from theirs.

- In terms of their multiculturality attitude scores, the students from Southeastern Anatolia regard multiculturality as richness, not as a threat, unlike students from other regions. Similar results have been obtained from students in Eastern Anatolia as well.

Among the results of the study, the relationship between "parents' educational status, family income level, ethnic structure and geographical region" was found to be particularly important for determining multiculturality attitudes. According to this, participants whose parents were literate and illiterate and, similarly, those whose income level was 1000 TL and less were concentrated in the Southeastern and Eastern Anatolian regions. In addition, these regions were seen to vary more than others ethnically (Kurds, Turks, Zaza and Arab participants). Participants in these two regions were significantly more positive towards multiculturality, particularly in the "Richness" (Southeastern Anatolia) and "Threat" (Southeastern and Eastern Anatolia) dimensions than participants in other regions. Similarly, Güngör, Buyruk and Özdemir (2018) concluded that the teacher candidates from Southeastern and Eastern Anatolian regions have a more positive attitude than teacher candidates from the other regions. Particularly when the results concerning parental educational status are considered regarding the reflections of the nation state ideology on education, it may be inferred that participants in these two regions whose parents stayed outside the school system (literate and illiterate) were less intensely affected by the formal ideology of the state and therefore less influenced by the homogenization and "otherizing" of education, and 
displayed more positive attitudes towards different identities and class groups. The fact that the perception of ethnically-based Threat was low in these two regions (higher attitude scores) and that diversity was perceived as Richness may be considered as positive reflections of ethnic and cultural differences existing peacefully together. Studies show that interaction with different ethnic groups reduce threat perceptions and prejudice, and increase positive multiculturality attitudes (Bağc1 \& Çelebi, 2017; Pettigrew \& Tropp, 2006; Verkuyten, Thijs \& Bekhuis, 2010).

To conclude, in an individual's development of attitudes, many factors -such as family, social and economic status, political views, gender, ethnic and religious structure and geographic environment- have an effect. The attitudes developing (or developed) in the minds of the individuals from those effects lead to the occurrence of "others" and some negative attitudes towards multiculturality according to various situations (gender-based approach, class-based, religious and ethnic discrimination). Such negative attitudes can interfere in people's ability to live together in society. Therefore, in order to minimize these negative attitudes towards multiculturality in society, people's awareness that different life practices by various groups within a country or community offers richness that should be recognized. Furthermore, a positive response to these social cultures should be developed. To achieve this, the regulation of educational experiences considering cultural diversity and normalizing transitions the differences in the educational institutions that serve as foundation in the societybuilding process is of the utmost importance. If a high-quality life away from intergroup conflicts is aimed, it is necessary to teach the students to establish closer relations with individuals from different ethnic backgrounds, races, cultures, languages and gender identities (Gay, 2014). Thus, instead of educational practices and relational processes with a monistic understanding that excludes the differences, the basis for positive perceptions and attitudes that will enable the ability to live together should be established. In this regard, ensuring that the students comprehend the richness of cultural differences and all belongings, instead of negative approaches and definitions towards differences, will contribute to the strengthening of the ability to live together and to the development of sustainability, which is one of the main objectives of the education. The acquisition of such behaviours through education also means to teach the students to assimilate the patterns related to geography as a spatial science and geographical education. Because one of the main aims of geography education, which is the teaching of human-space relations, is to analyze the human behaviours in the context of patterns of space. The discipline of geography examining the relation between human and space enables the analysis of socio-spatial productions such as belonging, identity and culture, and the social relations shaped in this direction through education and other interdisciplinary approaches. The introduction of multicultural issues in geography education will offer important opportunities and gains to social integration. Thus, in an education related to different cultural space imagination and patterns; it is claimed that a spatial production where multilateralism (heterogeneity), uniformity, harmony prevail against standardization (homogeneity), singularity, the conflict will produce more successful and inclusive possibilities. 


\section{References}

Açıkalın, M. (2010). Sosyal bilgiler eğitiminde yeni yaklaşımlar: Çokkültürlü ve küresel eğitim. İlkögretim Online, 9(3), 1226-1237.

Akar, C., \& Keyvanoğlu, A.(2016). 2009 ve 2015 Hayat bilgisi programlarının çokkültürlü eğitim bağlamında karşılaştırılması. Ahi Evran Üniversitesi Kırşehir Eğitim Fakültesi Dergisi (KEFAD), 17(2), 731-749.

Akhan, O., \& Yalçı, A. (2016). Sosyal bilgiler öğretim programlarında çokkültürlü eğitimin yeri. Trakya Üniversitesi Sosyal Bilimler Dergisi, 18(2), 23-46.

Akkaya, N., Kırmızı, F. S., \& İşçi, C. (2018). Öğretmen adaylarının çokkültürlülüğe ilişkin algılarının farklı değişkenler açısından incelenmesi. Adıyaman Üniversitesi Sosyal Bilimler Enstitüsü Dergisi, 10(29), 308-335.

Althusser, L. (2015). İdeoloji ve devletin ideolojik aygıtları (Trans. A. Tümertekin). İstanbul: İthaki Yayınları.

Apple, M. W. (2012). Eğitim ve iktidar/education and power. (Trans. E. Bulut). İstanbul: Kalkedon.

American Psychological Association [APA] (2002).Guidelines on multicultural education, training, research, practice and organizational change for psychologists. Retrieved from http://www.apastyle.org/manual/related/guidelines-multicultural-education.pdf

Arslan, Y. (2016). Kim daha iyi empati kuruyor- Empati üzerine mikro bir sosyolojik araştırma. Batman Üniversitesi Yaşam Bilimleri Dergisi, 6(2/1), 51-64.

Aslan, S. (2017). Sosyal bilgiler öğretmenlerinin çokkültürlü eğitim ile ilgili görüşlerinin incelenmesi. Ahi Evran Üniversitesi Kırşehir Eğitim Fakültesi Dergisi (KEFAD), 18(2), 231-253.

Atış, F. (2010). Ebelik/Hemşirelik 1. ve 4. sinıf ögrencilerinin toplumsal cinsiyet rollerine ilişkin tutumlarınin belirlenmesi. (Unpublished Master's Thesis). Çukurova Üniversitesi/ Sağlik Bilimleri Enstitüsü, Adana.

Avc1, E. K., \& Faiz, M. (2018). The metaphors of secondary school teachers towards the concept of "Multiculturalism". Journal of Education and Training Studies, 6(5), 179-188.

Aytaç, Ö. (2016). Kent, yoksulluk ve sosyal düzensizlik potansiyeli. Mukaddime, 7(1), 135155.

Bağcı, S. Ç. \& Çelebi, E. (2017). Gruplararası temas ve çatışma ile azınlıklara yönelik tutumlar ve çokkültürlülüğe destek arasındaki ilişkiler: Gruplararası tehdit ve kaygının aracı rolü. Türk Psikoloji Yazıları, 20, 3-18.

Baker, C. (2013). Zorunlu eğitime hayır!/ Insoumission a l'ecole Obligatoire. İstanbul: Ayrınt1 Yayınları.

Banks, J. A. (2016). Multicultural education: Characteristics and goals. In J.A Banks \& C.A.M. Banks (Eds.), Multicultural education: Issues and perspectives $\left(9^{\text {th }}\right.$ ed., pp. 2-23). Hoboken, NJ: Wiley.

Banks, J.A. (2013). Çokkültürlü eğitime giriş/ An introduction to multicultural eduation (Trans. H. Aydın). Ankara: Anı Yayıncılık. 
Köşker, N., Özgen, N. (2018) Multiculturality concept and its reflections on education: The case of....

Baumann, G. (2006). Çokkültürlülük bilmecesi: Ulusal, etnik ve dinsel kimlikleri yeniden düşünmek (Trans. I. Demirakın). Ankara: Dost Kitabevi.

Bloom, S. G. (2005). Blue-eyes, brown-eyes: The experiment that shocked the nation and turned a town against its most famous daughter. Retrieved from http://www.uiowa.edu/ poroi/seminars/ 2004-5/bloom/poroi_paper.pdf

Bondi, S., Heasley C., Kolko, V. B., \& Young, S. (2003). White students' attitudes and behaviors toward people of color. Journal of the Indiana University Student Personnel Association at Indiana University, 80-96. Retrieved from http://scholarworks.iu.edu/journals/index.php/jiuspa/article/view/4627

Büyüköztürk, Ş. (2010). Sosyal bilimler için veri analizi el kitabi. Ankara: Pegem A Yayınları.

Çakırer, Y. (2006). Onlar olmasa evimizi kim temizleyecek? Korunaklı yaşamıyla Adana vars11. Kebikeç, 21, 211-230.

Çalışkan, H., \& Sağlam, H. İ. (2012). Hoşgörü eğilim ölçeğinin geliştirilmesi ve ilköğretim öğrencilerinin hoşgörü eğilimlerinin çeşitli değişkenler açısından incelenmesi. Kuram ve Uygulamada Eğitim Bilimleri, 12(2), 1431-1446.

Cansabuncu, S. (2008). Ortaöğretim öğrencilerinin milliyetçilik algısı: Zeytinburnu örneği. (Unpublished Master's Thesis). Beykent Üniversitesi/ Sosyal Bilimler Enstitüsü, İstanbul.

Cırık, İ. (2008). Çok kültürlü eğitim ve yansımaları. Hacettepe Üniversitesi Eğitim Fakültesi Dergisi, 34, 27-40.

Cohen, L., Manion, L. \& Morrison, K. (2007). Research methods in education. (6th Edition) London: Routledge.

Creswell, J. W. (2009). Research Design: Qualitative, quantitative, and mixed methods approaches. Thousand Oaks, CA: SAGE Publications.

Çayır, K. (2003). Ders kitaplarında insan hakları ve demokrasi bilinci. In B. Çotuksöken, A. Ersan \& O. Siler (Eds.) Ders kitaplarında insan hakları tarama sonuçları (pp. 90-105). İstanbul: Tarih Vakfı Yayınları.

Çayır, K. (2016). Türkiye'de ulusal kimliği yeniden tanımlama yolunda özcülük, çokkültürlülük ve kültürlerarası eğitim. Eğitim Bilim Toplum Dergisi, 14(55), 77-101.

Çoban, A. E., Karaman, N. G., \& Doğan, T. (2010). Öğretmen adaylarının kültürel farklılıklara yönelik bakış açılarının çeşitli demografik değişkenlere göre incelenmesi. Abant İzzet Baysal Üniversitesi Eğitim Fakültesi Dergisi,10(1), 125-131.

Çolak, Ö. (2009). Eşcinsellere yönelik nefret suçları ve toplumun bu suçlar kapsamında faile ve mağdura yönelik tutumları. (Unpublished Master's Thesis). İstanbul Üniversitesi/Adli Tıp Enstitüsü, İstanbul.

Coşkun, M. K. (2012). Din kültürü ve ahlak bilgisi öğretmen adaylarının çokkültürlü eğitime yönelik tutumları: İlahiyat-eğitim DKAB karşılaştırması. Dumlupınar Üniversitesi Sosyal Bilimler Dergisi, 34, 33-44.

Damgacı, F., \& Aydın, H. (2013). Akademisyenlerin çokkültürlü eğitime ilişkin tutumları. Elektronik Sosyal Bilimler Dergisi-Electronic Journal of Social Sciences, 12(45), 325341. 
Demir, S., \& Başarır, F. (2013). Çokkültürlü eğitim çerçevesinde öğretmen adaylarının özyeterlilik algilarının incelenmesi. International Journal of Social Science, 6(1), 609-641. doi:http://dx.doi.org/10.9761/JASSS_489

Demir, S. (2012). Çok kültürlü eğitimin Erciyes Üniversitesi öğretim elemanları için önem derecesi. Turkish Studies - International Periodical For The Languages, Literature and History of Turkish or Turkic, 7(4), 1453-1475. doi:http://dx.doi.org/10.7827/ TurkishStudies.3871

Demirsoy, M. (2013). Sosyal bilgiler öğretmen adaylarının çokkültürlülüğe ilişkin görüşleri ve çokkültürlü eğitime yaklaşımları. (Unpublished Master's Thesis). Marmara Üniversitesi/ Eğitim Bilimleri Enstitüsü, İstanbul.

Engstrom, C. M., \& Sedlacek, W. (1997). Attitudes of heterosexual students toward their gay male and lesbian peers. Journal of College Student Development, 38(6), 565-576.

Field, A. (2009). Discovering statistics using SPSS: (and sex and drugs and rock 'n' roll). London: SAGE.

Fortna, B. (2013). Geç Osmanl ve Erken Cumhuriyet dönemlerinde okumayı ögrenmek/Learning to read in the Late Ottoman Empire and early Turkish Republic (Trans: M. Beşikçi). İstanbul: Koç Üniversitesi Yayınları.

Foucault, M. (2011). Özne ve iktidarl Dits et écrits (1954-1988). (Trans. I. Ergüden \& O. Akınbay). İstanbul: Ayrıntı yayınları.

Gay, G. (2014). Kültürel değerlere duyarlı eğitim: Teori, araştırma ve eğitim/Culturally responsive teaching: Theory, research, and practice. (Trans ed. H. Aydın). Ankara: Anı Yayıncilik.

George, D., \& Mallery, M. (2010). SPSS for windows step by step: A simple guide and reference, 17.0 update (10a ed.) Boston: Pearson.

Gök, F. (2003). Vatandaşlık ve insan hakları eğitimi ders kitapları. In B. Çotuksöken, A. Ersan \& O. Siler (Eds.) Ders kitaplarında insan hakları tarama sonuçları (pp. 158-171). İstanbul: Tarih Vakfı Yayınları.

Gömleksiz, M. N., \& Çetintaş, S. (2011). Öğretmen adaylarının demokratik tutumları (Fırat, Dicle,7 Aralık, Cumhuriyet ve Erzincan Üniversiteleri örneği). Dicle Üniversitesi Ziya Gökalp Eğitim Fakültesi Dergisi, 17, 1-14.

Günay, M. (2010). Çokkültürlülük gerçeği ve Türkiye. Kaygl, 14, 141-151.

Güngör, S., Buyruk, H., \& Özdemir, Y. (2018). Öğretmen adaylarının çokkültürlülüğe ilişkin tutumları. Elektronik Sosyal Bilimler Dergisi, 17(66), 816-837.

Hasta, D., Güler, M.E. (2013). Saldırganlık: kişilerarası ilişki tarzları ve empati açısından bir inceleme. Ankara Üniversitesi Sosyal Bilimler Enstitüsü Dergisi, 4(1), 64-104.

İlğan, A., Karayiğit, D., \& Çetin, B. (2013). Ortaokul öğrencilerinin demokratik değerlere sahip olma düzeylerinin çeşitli değişkenlere göre incelenmesi. Celal Bayar Üniversitesi Sosyal Bilimler Dergisi, 11(2), 97-118.

Kahraman, P. B., \& Sezer, G.O. (2017). Relationship between attitudes of multicultural education and perceptions regarding cultural effect of globalization. Eurasian Journal of Educational Research (EJER), 67, 233-249. 
Köşker, N., Özgen, N. (2018) Multiculturality concept and its reflections on education: The case of....

Karaçam, M.Ş., \& Koca, C. (2012). Beden eğitimi öğretmen adaylarının çokkültürlülük farkındalıkları. Spor Bilimleri Dergisi, 23(3), 89-103.

Kaya, Y., \& Söylemez, M. (2014). Öğretmenlerin çokkültürlülük ve çokkültürlü eğitim hakkındaki görüşlerinin belirlenmesi: Diyarbakır örneği. Dicle Üniversitesi Sosyal Bilimler Enstitüsü Dergisi, 6(11), 128-148.

Keskin, Y., \& Yaman, E. (2014). İlköğretim sosyal bilgiler programı ve ders kitaplarında yeni bir paradigma: Çokkültürlü eğitim. Turkish Studies - International Periodical for the Languages, Literature and History of Turkish or Turkic, 9(2), 933-960.

Keyman, F. (2007). Türkiye'de kimlik sorunları ve demokratikleşme, Doğu Batt, 41, 217-227.

Kaplan, İ. (2005). Türkiye'de milli eğitim ideolojisi ve siyasal toplumsallaşma üzerindeki etkisi. İstanbul: İletişim Yayınları.

Kaplan, İ. (2008). Milli eğitim ideolojisi. In T. Bora \& M. Gültekingil (Eds.) Modern Türkiye'de siyasi düşünce: Milliyetçilik (pp.788-799). İstanbul: İletişim Yayınları.

Kim, H. Y. (2013). Statistical notes for clinical researchers: assessing normal distribution (2) using skewness and kurtosis. Restorative Dentistry \& Endodontics, 38(1), 52-54.

Kymlicka, W. (1998). Çokkültürlü yurttaşlık (Multicultural citizenchip). (Trans. A. Yılmaz) İstanbul: Ayrıntı Yayınları.

Lacoste, Y. (1998). Coğrafya savaşmak içindir. (Trans. A. Arayıc1). İstanbul: Özne Yayınları.

Modood, T. (2014). Çokkültürcülük: Bir yurttaşlık tasarımı/Multiculturalism: A civic idea. (Trans. İ. Yılmaz). Ankara: Phoenix Yayınevi.

Nayır, K.F. \& Çetin, S.K. (2018). Üniversite öğrencilerine göre çokkültürlü eğitim ve demokrasi. Akdeniz Egitim Arastirmalari Dergisi, 12(24), 229-252. doi: 10.29329/mjer.2018.147.13

Oktay, M. (1996). Davranış bilimlerine giriş. İstanbul: Der Yayınları.

Özdemir, M., \& Dil, K. (2013). Öğretmenlerin çokkültürlü eğitime yönelik tutumları: Çankırı ili örneği. Ankara Üniversitesi Ĕ̆itim Bilimleri Fakültesi Dergisi, 46(2), 215-232. doi:10.1501/Egifak_0000001302

Özensel, E. (2012). Çokkültürlülük uygulaması olarak Kanada çokkültürlülüğü. Akademik Incelemeler Dergisi (Journal of Academic Inquiries), 7(1), 55-70.

Özgen, H. N. (2011). Türkiye Cumhuriyeti'nin kuruluşundan günümüze, coğrafya ders kitaplarında, vatanın sonu gelmez kurguları. Toplum ve Bilim. 121,48-78.

Özgen, N. (2011). Geography perceptions of prospective geography teachers: Example of Turkey". E-Journal of New World Sciences Academy, 6(4), 2569-2587.

Özgen, N. (2012a). Coğrafyanın kurumsal temsiliyet ve kimlik krizi /Geography's institutional representation and its identity crisis. In C. Sevindi (Ed.), Atatürk Üniversitesi Edebiyat Fakültesi Coğrafya Bölümü I.Ulusal Coğrafya Sempozyumu Bildiriler Kitabı (pp. 555572). Erzurum: Atatürk Üniversitesi.

Özgen, N. (2012b). Bilim olarak coğrafya ve evrimsel paradigmaları/Geography as a science and its evaluative paradigms. Ege Coğrafya Dergisi, 19, 1-26. 
Özgen, N. (2013a). Perception of preservice teachers regarding the concept of erosion: A phenomenographic study. H.U. Journal of Education, 28(2), 321-334.

Özgen, N. (2013b.) A qualitative research on perception of geography by training teachers of geography: sample of Turkey. Higher Education of Social Science, 5(1), 25-34. doi: http://dx.doi.org/10.3968/j.hess.1927024020130501.4580

Özgen, N. (2016). A critical approach to discipline of human geography as an apparatus for state hegemony in Turkey. Journal of Geography in Higher Education, 40(1), 131-153.

Özgen, N., \& Köşker, N. (2015). Multiculturality attitude scale: A sample from Turkey. International Online Journal of Educational Sciences, 7(2), 121-129. doi:http://dx. doi.org/10.15345/iojes.2015.02.009

Özgen, N., \& Köşker, N. (2019). An analysis on multiculturality attitudes of high school students: The case of Turkey, Turkish Studies, 20(1), 69-91, doi:10.1080/14683849. 2018.1465342 (Early Edition).

Öztan, G.G. (2011). Türkiye'de çocukluğun politik inşası. İstanbul: İstanbul Bilgi Üniversitesi Yayınları.

Parekh, B. (2002). Çokkültürlülüğü yeniden düşünmek (Rethinking multiculturalism). (Trans: B. Tanrıseven), Ankara: Phoenix Yayınevi.

Polat, S. (2012). Okul müdürlerinin çokkültürlülüğe ilişkin tutumları. Hacettepe Üniversitesi Ĕ̈itim Fakültesi Dergisi, 42, 334-343.

Pettigrew, T. F. \& Tropp, L. R. (2006). A meta-analytic test of intergroup contact theory. Journal of Personality and Social Psychology, 90(5), 751-783.

PMAPD/Prime Ministry Administration of Persons with Disabilities (1997). Özürlülük eğitimi: Toplum özürlülüğ̈̈ nasıl anliyor temel araştırmast. Retrieved from http://www.eyh.gov.tr/upload/Node/8321/files/toplum_ozurlulugu_nasil_anliyor.pdf

Saraçoğlu, C. (2009). İzmirli orta sınıfta Kürt algısı: Mekân, sınıf ve kentsel yaşam. Praksis, 21, $17-46$.

Schmitt, C. (2010). Siyasal ilahiyat/ Politische Theologie. (Trans. A. E. Zeybekoğlu \& E. Özdoğan). Ankara: Dost Kitabevi.

Schutz, R. W. \& Gessaroli, M. E. (1993). Use, misuse, and disuse of psychometrics in sport psychology research. In R. N. Singer, M. Murphey \& L. K. Tennant (Eds.), Handbook of research on sport psyvhology (pp. 901-917). New York: Macmillan.

Seban, D., \& Uyanık, H. (2016). Türkiye'de çokkültürlü eğitim: 1-5. sınıf programlarında yer alan kazanımların analizi. Pegem Eğitim ve Ögretim Dergisi, 6(1), 01-18, http://dx.doi.org/10.14527/pegegog.2016.001.

Taylor, C. (2005). Tanınma politikası (The politics of recognition). In A. Gutmann (Ed.), Çokkültürcülük, tanınma politikası (Multiculturalism Examining the politics of recognition) (pp. 42-84). İstanbul: Yap1 Kredi Yayınları.

Ulugöl, M. C. (2009). Osmanlı ve Türkiye'de vatandaşlık kavramı, azınlıklar üzerinde etkisi ve uygulamaları. (Unpublished Master's Thesis). İstanbul Bilgi Üniversitesi/Sosyal Bilimler Enstitüsü, İstanbul. 
Uydaş, İ., \& Genç, S. Z. (2015). Ortaöğretim öğrencilerinin küresel vatandaşlık bağlamında çokkültürlülük hakkındaki görüşlerinin değerlendirilmesi. Uluslararası Türkçe Edebiyat Kültür Ĕgitim Dergisi, 4(1), 416-429.

Üstel, F. (2014). Makbul vatandaş"ın peşinde- II. Meşrutiyet'ten bugüne vatandaşlık eğitimi. Ankara: İletişim Yayınları.

Üzülmez, Y. K., \& Karakuş, F. (2018). Ortaokul ingilizce dersi öğretim programının ve ingilizce ders kitaplarının çokkültürlülük açısından incelenmesi. Turkish Studies Educational Sciences, 13(11), 773-802.

Verkuyten, M., Thijs, J. \& Bekhuis, H. (2010). Intergroup contact and ingroup reappraisal: Examining the deprovincialization thesis. Social Psychology Quarterly, 73(4), 398-416.

Vertovec, S. (2010). Towards post-multiculturalism? Changing communities, conditions and contexts of diversity. International Social Science Journal, 61(199), 83-95.

Weldon, S. (2006). The institutional context of tolerance for ethnic minorities: A comparative, multilevel analysis of Western Europe. American Journal of Political Science, 50(2), 331-349.

Wolf, S. (2005). Yorum (Interpretation). In A. Gutmann (Ed.), Çokkültürcülük, tanınma politikast (Multiculturalism-Examining the politics of recognition), (Trans. R. Urgan; pp. 85-94). İstanbul: Yapı Kredi Yayınları.

Yılmaz, D. V., Zeyneloğlu, S., Kocaöz, S., Kısa, S., Taşkın, L., \& Eroğlu, K. (2009). Üniversite öğrencilerinin toplumsal cinsiyet rollerine ilişkin görüşleri. Uluslararası İnsan Bilimleri Dergisi, 6(1), 775-792.

\section{Biographical Statements}

Nilüfer KÖŞKER is an assistant professor in the Department of Social Studies Education at Kırıkkale University in Kırıkkale, Turkey. Her research interests are geography education, education policy, multiculturalism, and multicultural education.

Nurettin ÖZGEN is an associate professor in Department of Geography at Ankara University in Ankara, Turkey. His research interests are on multiculturalism, multicultural education, geography education and its policies, critical human geography, migration and sociocultural attributions. 


\section{Appendix}

The Items and Factors of the Multiculturality Attitude Scale

\begin{tabular}{|c|c|c|c|c|c|c|}
\hline & The items & 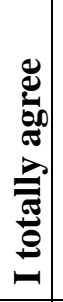 & 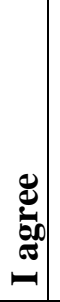 & 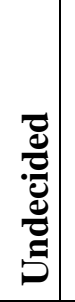 & 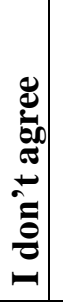 & 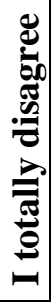 \\
\hline \multirow{6}{*}{$\frac{e^{2}}{2}$} & $\begin{array}{l}\text { A single religion (belief) should be dominant for an ideal } \\
\text { society.* }\end{array}$ & & & & & \\
\hline & I treat people according to their sects (Sunni, Alevi, etc.).* & & & & & \\
\hline & $\begin{array}{l}\text { I find values of other religions (traditions, clothing, rituals, etc.) } \\
\text { strange.* }\end{array}$ & & & & & \\
\hline & I find people of other political opinions dangerous. ${ }^{*}$ & & & & & \\
\hline & Women should not work without the permission of men.* & & & & & \\
\hline & It is men who have to work (earn a living) in the family.* & & & & & \\
\hline \multirow{5}{*}{ 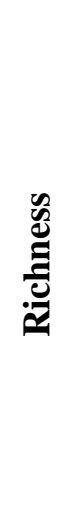 } & $\begin{array}{l}\text { I can be friends with someone who belongs to a different sect } \\
\text { (Sunni, Alevi) from me. }\end{array}$ & & & & & \\
\hline & $\begin{array}{l}\text { I feel disturbed by discrimination of ethnic groups (Arabic, } \\
\text { Circassian, Roma, Kurdish, Laz, Turkish, etc.). }\end{array}$ & & & & & \\
\hline & $\begin{array}{l}\text { I would like to be friends with people of different ethnic groups } \\
\text { (Arabic, Circassian, Roma, Kurdish, Laz, Turkish, etc.). }\end{array}$ & & & & & \\
\hline & The presence of various ethnic groups is richness for Turkey. & & & & & \\
\hline & $\begin{array}{l}\text { I would like to study various ethnic groups (Arabic, Circassian, } \\
\text { Roma, Kurdish, Laz, Turkish, etc.). }\end{array}$ & & & & & \\
\hline \multirow{3}{*}{ 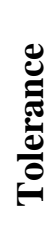 } & People should be able to freely express their sexual preferences. & & & & & \\
\hline & I find people with different sexual preferences normal. & & & & & \\
\hline & $\begin{array}{l}\text { I can be friends with a person whose sexual preference is } \\
\text { different. }\end{array}$ & & & & & \\
\hline \multirow{3}{*}{ 馬 } & Ethnic languages spoken around me irritate me.* & & & & & \\
\hline & Only one language should be spoken in an ideal state.* & & & & & \\
\hline & $\begin{array}{l}\text { I can't understand people who want to communicate in their } \\
\text { own mother tongues in Turkey (Arabic, Circassian, Roma, } \\
\text { Kurdish, Laz, Turkish, etc.).* }\end{array}$ & & & & & \\
\hline
\end{tabular}


Köşker, N., Özgen, N. (2018) Multiculturality concept and its reflections on education: The case of....

\begin{tabular}{|l|l|l|l|l|l|}
\hline & $\begin{array}{l}\text { Ethnic groups in the country (Arabs, Circassians, Kurds, Laz } \\
\text { and Turks) are a threat for the unity of the state.* }\end{array}$ & & & & \\
\hline Boys have the primary right to study in a family.* & & & & & \\
\hline & Disabled people can not be productive at work.* & & & & \\
\hline
\end{tabular}

* Attitude sentences including negative connotations. 